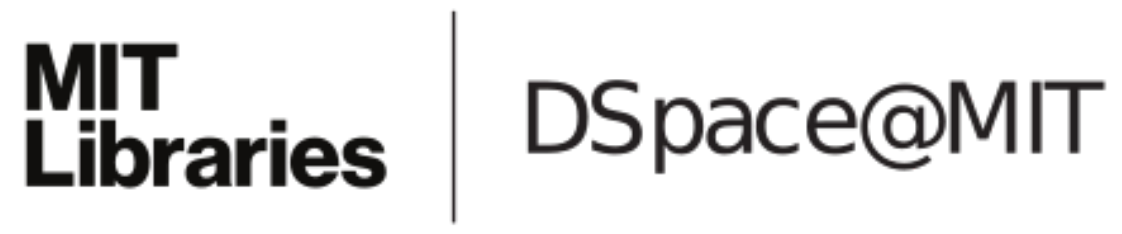

\author{
MIT Open Access Articles
}

Outspoken Insiders: Political Connections and Citizen Participation in Authoritarian China

The MIT Faculty has made this article openly available. Please share how this access benefits you. Your story matters.

Citation: Tsai, Lily L., and Yiqing Xu. “Outspoken Insiders: Political Connections and Citizen Participation in Authoritarian China." Political Behavior, vol. 40, no. 3, Sept. 2018, pp. 629-57.

As Published: https://doi.org/10.1007/s11109-017-9416-6

Publisher: Springer US

Persistent URL: http://hdl.handle.net/1721.1/117467

Version: Author's final manuscript: final author's manuscript post peer review, without publisher's formatting or copy editing

Terms of use: Creative Commons Attribution-Noncommercial-Share Alike 


\title{
Outspoken Insiders: \\ Political Connections and Citizen Participation in Authoritarian China*
}

\author{
Lily L. Tsai \\ Massachusetts Institute of Technology
}

\author{
Yiqing $\mathrm{Xu}$ \\ University of California, San Diego
}

\section{Compliance with Ethical Standards}

Conflict of Interest: The authors declare that they have no conflict of interest.

\begin{abstract}
Few political systems are completely closed to citizen participation, but in nondemocratic systems and developing democracies, such participation may come with risks. In these contexts where fear and uncertainty may be high, why do some citizens still take action and make complaints to authorities? The resource mobilization model identifies the importance of time, money, and civic skills as resources that are necessary for participation. In this paper, we build on this model and argue that political connections - close personal ties to someone working in government - can also constitute a critical resource, especially in contexts with weak democratic institutions. Using data from both urban and rural China, we find that individuals with political connections are more likely to contact authorities with complaints about government public services, despite the fact that they do not have higher levels of dissatisfaction with public service provision. We conduct various robustness checks, including a sensitivity analysis, and show that this relationship is unlikely to be driven by an incorrect model specification or unobserved confounding variables.
\end{abstract}

Keywords: authoritarianism; complaint making; state-society relations; political connections; political participation; resource model

\footnotetext{
${ }^{*}$ Lily L. Tsai, Associate Professor, Department of Political Science, Massachusetts Institute of Technology. Email: l_tsai@mit.edu. Telephone: (617) 253-6643. Yiqing Xu, Assistant Professor, Department of Political Science,

University of California, San Diego. Email: yiqingxu@ucsd.edu. Telephone: (617) 866-0547. Replication data and code for this paper can be downloaded from https://doi.org/10.7910/DVN/VXVBNI.
} 


\section{Introduction}

Given high levels of risk and uncertainty associated with political action in nondemocratic systems and developing democracies, why do we ever see ordinary citizens taking action to hold government authorities accountable by complaining about poor public goods provision? Crossnational survey data from these contexts show that fear of political retaliation is widespread. More than one-third of respondents, for example, in the last two rounds of the Arab Barometer survey (2010-2011 and 2012-2014) say that they are not able to criticize the government without fear. Data from the 2008 Afrobarometer survey show that most people have some fear of becoming a victim of political intimidation or violence during election campaigns, and that one-third of people fear it "somewhat" or "a lot." More than half of all countries in the world - 54 percent - were categorized as "not free" or "partly free" by Freedom House in 2015 (Freedom House 2015).

Many nondemocratic and hybrid regimes, however, do allow some measure of conventional participation, implementing formal channels to allow citizens to relay their complaints and criticisms (e.g. Botero, Ponce and Shleifer 2013; Dimitrov 2013). These channels provide authorities with feedback to help them address problems of governmental performance, manage citizen dissatisfaction, and minimize the potential for protest (e.g. Truex 2014, Chen, Pan and Xu 2015, Chen and Xu 2015 2016). And precisely because they can be so limited, citizens see these channels as critical opportunities for voicing their needs and opinions to authorities.

But it is not easy for citizens to know when they have overstepped the line of what is politically acceptable (Lorentzen 2014). Uncertainty about the outcomes of political action is a common problem in transitional systems and developing democracies. Formal procedures for contacting and accessing government officials are often unclear or unknown to ordinary citizens. 
Officials often have an interest in making the workings of government as "remote and incomprehensible" as possible (Khanna and Johnston 2007).

In American politics, the dominant resource mobilization model of political participation advanced by Verba, Schlozman, and Brady (1995) highlights the importance of time, money, and civic skills as resources that are necessary for citizens to take political action. While these resources are likely to be important for participation everywhere, would-be complainers in nondemocratic and transitional systems have additional challenges to overcome: barriers of access, information, and political risk. Time, money, and civic skills do little to overcome these challenges. As with consolidated democracies like the U.S., these resources are associated with wealth, education, and socioeconomic status in developing contexts as well (Verba, Nie and Kim 1978; Wolfinger and Rosenstone 1980). The difference is that in authoritarian regimes and developing democracies, the regime often views the wealthy and educated as potential opposition. This suspicion often exists for good reason. Scholars of the English, French, and Russian revolutions have long noted the key role of intellectuals in political change (Goldstone 1982). More recently, the intelligentsia and professional classes were central to the fall of communism in Eastern Europe (Chirot 1991).

If the time, money, and civic skills conferred by wealth and education provide little help in overcoming the political fear and uncertainty that frequently block civic participation outside of consolidated democracies, then what kinds of resources do citizens need in order to take action to hold government accountable? In this paper, we argue that political connections - defined as having close personal ties to someone working in public office - can constitute a critical resource for citizens who seek to engage in civic participation that holds the government accountable for the provision of public goods. 
There is, of course, a large cross-national literature on patronage and clientelism that also highlights the importance of personalistic ties. Theories of clientelism argue that instead of engaging civic participation to hold government authorities accountable, citizens in developing contexts instead pursue particularistic benefits. Clientelistic relationships with patrons and brokers enable individuals to sell their votes or political support in exchange for private goods employment opportunities, access to welfare programs, or even cash. In these models, individuals with high socioeconomic status are the least likely to engage in civic participation to hold government accountable. They have their wealth, education, and many organizational skills because they have been coopted or bought off by the regime in exchange for political quiescence.

We find, however, that political connections can sometimes constitute a resource for civic participation, not just clientelistic exchange. Political connections may sometimes be used for personal gain - but political connections can also enable citizens to engage in participation that is civic-minded rather than particularistic. This paper thus contributes on the one hand by refining the resource mobilization model of participation for developing contexts and identifying political connections as another important resource affecting political behavior in developing countries. It also contributes, on the other hand, to the literature on patronage and clientelism by suggesting that political connections can - sometimes simultaneously - serve as resources for both civic participation and clientelistic politics. "Informal institutions and personalized relationships," as one recent report observes, "are pervasive and powerful and can contribute to progressive outcomes in poor countries" [emphasis added] (Institute of Development Studies 2010).

Our conceptualization of political connections as a resource for civic participation also diverges from the large literature in American politics on the importance of networks and interpersonal relationships in political mobilization (Rosenstone and Hansen 1993; Gerber and Green 2000; Gerber, Green and Larimer 2008). In this line of inquiry, political connections to 
politicians, political parties, and activists are important because they shape the political incentives that citizens are offered for participation. In other words, the people in your networks are important because politically active individuals may ask you to take action to influence the government decisions. We argue, however, that in nondemocratic regimes and developing contexts the more important questions facing a would-be participator are whether people in your networks can help you know how to participate, access the people you want to influence, and ensure that your action does not result in reprisal.

To demonstrate the importance of political connections as a resource for civic-minded participation, we draw on data from two surveys, one conducted in 2013 of urban residents in China's provincial capital cities and one conducted in 2008 of rural residents from a nearly nationally representative sample. China provides a useful case of a political system that lacks national-level elections or a multiparty system, yet allows enough room for criticism from citizens so as to have substantial variation in individual political behavior to analyze. Our data show that a large proportion of survey respondents in both urban and rural areas report that they have made recent complaints about civic concerns such as government provision of public goods to local authorities.

China is also an important case for in-depth examination since it is often upheld as a model case of authoritarian durability (e.g. Nathan 2003). Looking more closely at citizen participation and interaction with local state institutions enables us to assess the micro-foundations of this durability. If nondemocratic regimes are able to obtain sufficient levels of honest and helpful feedback on government performance through the formal channels they provide, and this feedback comes from individuals who are unlikely to mobilize a revolution against the regime, then such regimes may be able to create stable and enduring relationships between citizens and the state. 


\section{Political Connections as a Resource}

Individuals everywhere face the problem of having sufficient resources for political action. In developing their resource mobilization model of political participation, Verba, Schlozman, and Brady (1995) ask the question, why don't people take more political action? Their answer, which draws on the experience of consolidated democracies like the United States, highlights the need for individuals to have enough time, money, and civic skills to act. In order to contribute to a campaign or political cause, an ordinary American needs money. Similarly, in order to write a letter to a public official or work on a campaign, people need enough free time to do so. Organizational and communications skills are also important since those who are good at public speaking or organizing a meeting are likely to be more effective when they get involved in politics.

Asking the same question, however, in nondemocratic or transitional systems focuses our attention on obstacles of political risk and uncertainty. Citizens in these systems often do not take action because they are uncertain of how to do so and afraid of what might happen (Lieberman, Posner, and Tsai 2014). Lack of government transparency can make it difficult for individuals to know how to take action and access officials (Tarrow 1998). Information about how best to submit complaints is eagerly sought but difficult to obtain. Rules about participation and rights to participate may be constantly changing, weakly enforced, or nonexistent. Authority is exercised in "highly personalized, non-transparent ways" (Institute of Development Studies 2010). Criticizing and complaining about government performance in these regimes - even constructively and through formal channels - can be a risky prospect when there are no guarantees that one will not be punished in some way for saying something negative about the government. 
Political connections - personal or familial connections to those in public office - have long been recognized in these contexts as an important political resource but one that has almost exclusively been studied as something actors use in pursuit of material interest and private gain. Social scientists typically equate "connections" with the ability to obtain preferential treatment and unfair benefits through informal or illicit means. Political scientists studying patronage and clientelism have also thoroughly documented the use of personal, affective relationships for instrumental exchange and personal favoritism (Kitschelt and Wilkinson 2007). Banfield (1967) and Scott (1972), for example, illuminated the role of patron-client ties in traditional societies where individuals are asked to support elite objectives in exchange for material benefits. Studies of blat in Russia and guanxi in China describe similar dynamics (e.g. Ledeneva 1998; Gold, Guthrie and Wank 2002). More recently, in rural Egypt, Blaydes (2006) has observed that voters are frequently involved in long-term clientelistic or familial relationships with political candidates in the hopes of obtaining jobs and other benefits for themselves and their families. Lust-Okar (2006) finds in Jordan that many people vote for a candidate with whom they have close personal ties because they are more confident such a candidate will channel selective benefits to them. Elites in these "patronage democracies" channel economic benefits to voters with whom they have relationships of kinship or personal loyalty (e.g., Chandra 2004, 2012; Besley, Pande and Rao 2007).

There is also a large body of empirical work in economics that has sought to quantify the value of political connections for business firms in both developing and developed countries (e.g. Fisman 2001; Johnson and Mitton 2003; Khwaja and Mian 2005; Knight and Johnson 2007; Amore and Bennedsen 2013). The assumption of this literature is that political connections are associated with rent-seeking behavior, cronyism, and state capture. Connections allow firms to secure preferential access to credit, business licenses, land, tax benefits, and government 
procurement contracts (Li, Meng, Wang and Zhou 2008; Goldman, Rocholl and So 2013). Connections can also provide firms with better access to courts and political influence over adjudication (Ang and Jia 2014).

A growing literature, however, on transitional systems and developing contexts highlights the importance of political connections for civic and political engagement (e.g. Boone 2003; Jennings 1997; Manor 2000). Duara (1988) notes that throughout the developing world, ordinary people often need the help of a broker who has political connections in order to access the government. Krishna $(2002,2011)$ finds that the existence of new, non-caste based village leaders increase levels of political participation in villages with high social capital by providing political information and direction. While some of this participatory activity is motivated by particularistic concerns, some of it is also directed at improving governmental performance and public goods provision.

Building on these insights, we refine the resource-mobilization model of participation by proposing that political connections can constitute a critical resource for autonomous participation in nondemocratic and transitional systems, where government transparency and the rule of law are often weak. While people need the free time to go and engage in a political activity, or the public speaking skills to articulate a complaint effectively to someone in power, individuals in nondemocratic systems and developing democracies also need access to decision makers, information about the government's policies and procedures, and protection against the risk of political retribution.

Access to government decision makers is a central issue for citizen participation in nondemocratic and transitional systems. In his study of Mexico, for example, Hofmann (2006) describes how "the culture of stealth and pretense, of opacity, of corruption and distrust created 
walls between the federal public administration and the citizens." Personal connections to someone in government can make the difference between being stonewalled by an incomprehensible bureaucracy and being able to talk to an actual person. As Milgram (1967) and other social network theorists have documented, interpersonal ties are essential for being able to reach or communicate a particular message to a particular target person (Granovetter 1973; Milgram 1967; Travers and Milgram 1969; Korte and Milgram 1970). Not only do individuals with political connections find it easier to obtain a face-to-face meeting with government officials - but they can also find it easier to access the right official for the complaint they wish to have addressed (McGee and Gaventa 2010; Ghertner 2011; Khagram, Fung and de Renzio 2013). Brokers and mediators in India, for example, with connections in the bureaucracy are often instrumental in expediting the processing of claims by citizens and the resolution of grievances (Baviskar 2010; Jenkins 2007). In an authoritarian context, Ang and Jia (2014) and Michelson (2007a) find that individuals can use these connections to access higher-level officials.

Political connections can also provide individuals with political knowledge and "knowhow" about how to negotiate the system - or access to sources that have the specific information they need about a particular government policy or procedure they need in order to take action. Citizens in these contexts often lack information about the formal and informal opportunities for engaging in government decision-making processes (Folscher 2010; Carter 2013; Lieberman, Posner and Tsai 2014). Ethnographic studies of the state in developing contexts have highlighted the pervasiveness of "opaque and informal conduits and connections" in political society and "the everyday state" (Webb 2012; Chatterjee 2004; Fuller and Benei 2000; Ghertner 2011). At the same time, knowledge of these channels and opportunities can be essential for enabling the urban poor to survive (Visvanathan 2008). Thus, both paid brokers (dalaal) and civil society activists in India enable citizens to make complaints to government agencies about delays in welfare claims 
by directing them to the relevant government office and filling out the correct forms - know-how that ordinary people do not have (Webb 2012; Corbridge and Kumar 2002; Ruud 2000). In Mozambique, politically connected individuals are better able to push through legal changes in land use rights (Fairbairn 2013). In China, Michelson (2007a) finds that citizens use political connections to obtain information about government policies and working procedures.

Third, an individual's political connections can provide protectors and "guarantors" who can vouch for one's trustworthiness and/or political loyalty. Givens (2011) and Michelson (2007b) find that journalists in Russia, as well as lawyers and journalists in China, make use of networks with officials as protection mechanisms in case of retaliation by authorities.

Connections to those in office can act as "markers of upstanding citizens" and provide a "deterrent effect" to those who might retaliate (Givens 2011). Similarly, Shi (1997) notes that "few would hesitate to contact officials at higher levels and persuade them to intervene on their behalf if local government officials launched unauthorized retaliation against them.... With such important political resources in their hands, these people may perceive substantially lower risks in adversarial activities than ordinary people in the society do."

Personal connections can thus substitute in some ways for formal membership in statesponsored organizations or even civic associations. Shi (1997) has observed, for example, that Party members in China have more opportunities to access higher-level officials, more familiarity with the government's policies, and the ability to ally themselves with higher-level officials in order to force more favorable outcomes in their conflicts with lower-level officials. O'Brien and Li (2004) note that Party members can have strategic advantages when complaining to higher levels about the failure of lower levels to follow the letter of the law. Guo (2007) also notes that membership in both civic associations and the Communist Party is correlated with better connections, higher levels of political knowledge, and more external efficacy and that Party 
membership can be counted on as a protective shield: "Even if legal action is brought on the perpetrator, expulsion from the Party or League normally leads to a less severe criminal or administrative punishment." Like membership in social organizations, the participatory resources provided by political connections may have salutary effects on individual beliefs in internal and external efficacy.

Close-range field studies of developing contexts support the view that the same connections can be used by the same people for different purposes at different times. Singerman (1995) describes how, in urban Egypt, individuals use informal networks with government officials both as a private resource to obtain individual benefits such as government-distributed subsidized goods and as a public resource that fulfills the shared needs of their community to obtain public goods and services. Lam (1997) finds that Taiwanese farmers use the same personalistic relations both to hold local officials accountable for irrigation system maintenance and to secure particularistic benefits from candidates in local elections. Bratton (1994) notes that farmers in Senegal use local patronage networks to engage also in policy advocacy.

Rather than assuming that political connections are used exclusively for personal gain, people sometimes use them in pursuit of civic ends and the public good. An individual whose uncle works in the municipal tax bureau may indeed have an advantage when it comes to obtaining a tax break for his business - but he may also be able to obtain useful information on how to help others in his community register a collective petition from about illegal fees levied by local officials.

In the rest of the paper, we draw on empirical evidence from both urban and rural China to show a robust relationship between a person's political connections and his or her complaintmaking behaviors to government authorities on local public goods provision. We also assess 
factors that may be contributing to this relationship. Is this relationship, for example, driven by higher levels of dissatisfaction among individuals who have political connections? Our data suggest that individuals who have political connections are not more dissatisfied and motivated to participate than people who lack connections. Instead, we argue that individuals who have relatives who are government or village authorities participate more because they are equipped with more political knowledge and access to government decision makers. Our data also suggest that insiders generally have similar substantive concerns as outsiders (Online Appendix Figures 1 and 2).

These findings have important implications for authoritarian durability. One common concern is that insiders have different concerns than outsiders. Michelson (2007a), for example, has speculated that if insiders are able to use formal channels to voice these concerns more effectively than outsiders, outsiders may come to resent insiders and turn to destabilizing protest as a way of making their complaints heard. Our data suggest, however, that insiders and outsiders have similar concerns so, in a sense, insiders may simply represent concerns that they share with outsiders to the political system.

In the next section, we discuss data sources and empirical strategies. We then present the main empirical findings and report results for various robustness checks, including a sensitivity analysis. The last section concludes.

\section{Data and Empirical Strategies}

As liberalization has progressed over the last few decades, the Chinese government has broadened the space for complaints to authorities about government performance. Various reforms to allow for citizen criticism and input have been implemented, including institutions such as citizen complaint bureaus (Chen 2012), administrative lawsuits (O’Brien and Li 2004; Liebman 
2011), and citizen assemblies (He and Warren 2011). Authorities clearly tolerate at least some expression of negative opinion and immediate repression does not automatically result when citizens make complaints about the government. Nevertheless, the party-state remains deliberately vague about how large the scope for critical action is.

Our main objectives for this study are to investigate the resources that citizens need in order to make complaints about public goods provision and civic concerns to authorities under conditions of uncertainty and risk. To evaluate the importance of political connections for wouldbe complainers, we examine the data from two different surveys, one of urban residents conducted in almost all of China's provincial capital cities in 2013 and one of rural residents conducted in a nearly nationally representative sample in $2008 .^{1}$

Looking at both urban and rural China enables us to examine whether political connections provide important resources for civic participation in contexts that have somewhat different modes and channels for complaining to authorities - but that share the conditions of uncertainty and risk. Urban residents, for example, generally have a greater range of channels for complaining to authorities about government provision of public good and services. They can visit authorities in person, but they can also phone government hotlines. While such channels may be open to rural residents as well, rural residents often do not know about these alternatives and may only make complaints to village authorities face to face.

In both cases, however, complainers face significant uncertainty about things like what regulations govern how complaints are handled, what the correct procedures are for making an effective complaint, and who really has authority and power to resolve the complaint. In terms of

\footnotetext{
${ }^{1}$ In the urban survey, Lhasa in Tibet was not included and Karamay replaced Urumqi in Xinjiang due to implementation issues. In the rural survey, Tibet and Xinjiang were not included for the same reason. The urban surveys conducted in 2008 and 2010 show the exact same pattern as what we report in the next section, but the questions on compliant-making are less precise and less detailed in these two waves than in the 2013 survey.
} 
risk and fear, complaints made over the phone at arms' length to authorities whom one does not personally know may carry less risk than complaints made in person to the village committee. According to one vice-mayor in Beijing, however, complaint hotlines often require the name and contact information of the complainer to resolve complaints that are specific to a community, at which point citizens often hang up and abort their attempt to complain. ${ }^{2}$ Thus, it may be that both uncertainty and risk are important challenges for residents in both urban and rural China.

The urban data come from the China Public Governance Survey (CPGS), which surveyed more than 6,000 households. Urban sample size is a function of city size; in cities with a population greater than ten million (including Beijing, Shanghai, Tianjin, and Chongqing), no fewer than 300 households were surveyed. In cities with a population of five to ten million, at least 250 households were surveyed. In cities with a population of two to five million, 200 households were surveyed. In cities with a population fewer than two million people, 150 households were surveyed. The respondents were randomly selected using a geographic grid sampling strategy. The survey areas were first evenly divided into geographic squares. A set number of squares were randomly selected in each city and approximately 20-30 households were surveyed within each square to meet the requirement of the number of observations. To preserve sample representativeness, no more than 10 households were surveyed in the same neighborhood.

The rural data come from China Rural Governance Survey (CRGS), which surveyed 2,000 households in 2008. To date, it is still the most recent comprehensive and nationally representative household survey that focuses on local governance in rural China. CRGS employed a stratified clustering sampling strategy. One province was randomly selected from each of China's four major agro-ecological zones: Jiangsu from the eastern coastal region, Sichuan from the southwest, Shaanxi from the northwest, Hebei from the central region, and Jilin from the

\footnotetext{
${ }^{2}$ Author's interview, vice-mayor of a city within the jurisdiction of Beijing's provincial administration, April 3, 2008.
} 
northeast. Five counties were then randomly sampled from each province, two townships from each county, two villages from each township, and twenty households from each village. ${ }^{3}$

\section{Measurement of dependent variables}

The main dependent variables of this paper are measures of respondents' complaint-making behavior. To assess whether politically connected citizens are more likely to make complaints to authorities about government performance, we look at the following behavioral outcomes. In the urban survey, respondents were asked,

"During the past year, have you ever raised questions, complaints, or dissatisfaction against the local government or government officials in the following ways?"

The question was asked repeatedly with 14 different options for ways in which one can file a complaint, including visiting government offices, calling government hotlines, and contacting government officials. ${ }^{4}$ We constructed a variable measuring complaint making to the local government that equaled one if the respondent answered they had raised complaints using any of these channels. Table 1 in the Online Appendix presents the summary statistics. It shows that 15 percent of urban residents had complained to the local government. ${ }^{5}$ We also look specifically at complaint making through visits to government offices, the most frequently used channel by the citizens (3.9 percent).

\section{[FIGURE 1 ABOUT HERE]}

The CPGS also asked the respondents what they complained about if they had filed a complaint during the past year. Figure 1(a) shows that the majority of the complaints were about

\footnotetext{
${ }^{3}$ Per capita gross value of industrial output was used for stratification since it is often more reliable than official Chinese statistics on rural net per capita income and is one of the best predictors of standard of living. See Rozelle (1996). Respondents for questions about individual political attitudes and behavior were not randomly selected; survey enumerators interviewed either the first adult they encountered in the household or the household head. ${ }^{4}$ See Online Appendix for the complete list of options.

${ }^{5}$ The proportion of respondents who refused to answer the questions or were unable to do so is very small. When we use a multiple imputation procedure to deal with the missing data, the results remain almost identical.
} 
government performance and provision of public services, such as food and drug safety, transportation, public security and utilities.

To measure complaint making to authorities about government performance in the rural survey, respondents were asked,

"Have you raised problems about the quality of public projects with village authorities?"

In the context of rural China, the term "public projects" is understood to be public infrastructural projects - school buildings, road and bridge construction, and irrigation systems - that are typically organized and financed in large part or completely by village authorities and local governments. While village authorities are officially considered "self-government organizations" in the constitution, they are on the government payroll and are responsible for implementing state policies and regulations such as birth control quotas. Both citizens and government officials see village authorities as the lowest de facto level of public administration.

We also look at the following question as a secondary measure of public criticism of government public goods provision:

"Have you raised problems with the quality of public projects with other villagers?"

Though it is not a direct measure of citizen interaction with government authorities, within a nondemocratic context, individuals who raise criticisms of government actions in public are still engaging in meaningful civic and political action. Table 1 in the Online Appendix shows that 37 percent of rural respondents reported that they had made complaints to village authorities, and 49 percent reported that they had complained to fellow villagers. ${ }^{6}$

\footnotetext{
${ }^{6}$ Note that these data suggest much higher rates of complaint-making that Michelson (ASR 2007). In his 2002 survey, only 6.3 percent of his sample reports making any kind of complaint to village leaders. One possible explanation is that their survey used local teachers as survey enumerators. While the use of local teachers has some advantage due to shared dialects, it may also have increased response bias due to political sensitivity concerns and have decreased
} 


\section{Measurement of independent variables}

In this paper, we define political connections in its most narrow sense, namely, kinship ties with people who work in the administrative system. In the urban survey, respondents were asked,

"Do you have a relative or a family member who works at a government agency?"

In the rural survey, respondents were asked,

"Do you have any relatives who have worked in the village committee or higher levels of government, such as the township, county, or provincial government?"

Table 1 in the Online Appendix shows the descriptive statistics. Roughly 12 percent of respondents in the urban survey reported that they were politically connected, while in the rural area, 21 percent of the respondents reported that they were politically connected. For brevity, we call those who are connected "insiders" and those who are not "outsiders."

Table 1 in the Online Appendix also shows that in both urban and rural areas, insiders were much more likely to file complaints to authorities. For example, in the urban area, 25 percent of the insiders reported that they have filed a complaint to the government during the past year; the number was only 14 percent for outsiders. The contrast is equally sharp in rural areas: 45 percent for insiders versus 35 percent for outsiders. Although it is surely too hasty to claim a causal relationship between a respondent's connections and his or her complaint-making behavior at this stage, a strong empirical pattern clearly exists.

Both the urban and rural surveys collected information on respondents' socio-economic characteristics, which allow us to compare of the profiles of insiders and outsiders. In both urban and rural areas, on average, insiders and outsiders were about same age. In the urban area,

reporting of complaint-making with local villagers being reluctant to report their complaint making to teachers who has local elites may have ties to local authorities. 
insiders on average received one additional year of education than outsiders, while in the rural area, the difference is about half a year. The proportions of urban residents who held local, urban Hukou (household registration status) are about the same among insiders and outsiders. In both urban and rural areas, insiders were more likely to be members of the Chinese Communist Party (CCP) and from richer families than outsiders. In terms of occupation, in urban areas, insiders were more likely to take white-collar, non-government jobs than outsiders; in rural areas, they were more likely to receive earning from non-agricultural jobs than outsiders. Insiders were also more likely to be government officials or village cadres themselves. However, the majority of them (roughly 85 percent in both rural and urban areas) did not work in the government or village administration. $^{7}$

\section{Empirical strategies}

To investigate the relationship between a respondent's political connections and his or her complaint-making behavior, we estimate a logistic model controlling for a full set of regional fixed effects at the administrative district in urban areas and the village level in rural areas. The outcome variable indicates whether a respondent had filed a complaint recently. The key independent variable is a dummy variable indicating whether he or she is politically connected (1 when he or she is connected and 0 otherwise). We also control for a set of control variables, including individual-level socioeconomic characteristics. In all the regressions reported in this paper, standard errors are clustered at the urban district or rural village level.

The main quantity of interest is the marginal effect of political connections. If the model is correctly specified and being political connected is conditionally independent of the potential

\footnotetext{
${ }^{7}$ The high average age for the rural sample is likely due to out-migration, and the high percentage of males is likely due to the fact that household heads generally served as respondents for the survey questions on individual political attitudes and behaviors.
} 
outcomes of complaint-making after we control for the covariates and regional fixed effects, then the relationship between a respondent being politically connected on his/her probability of filing complaints to government authorities can be interpreted as causal. In other words, the identifying assumption requires that once we take the observed control variables and unobserved regional fixed effect into account, there are no other confounding factors that can systematically explain the difference in the propensity of filing complaints between insiders and outsiders. Note that the regional fixed effects absorb the effects of potential omitted variables at or beyond the regional level, such as geography, culture, regional policies, and level of development, so we are essentially making comparisons between insiders and outsiders within each geographic area (an urban district or a rural village). ${ }^{8}$

Two major concerns remain for the causal identification of the effect of political connections. First, the model can be incorrectly specified. For example, there could be non-linear or interactive relationships between the key independent variable, the control variables, and the outcome variable. Second, there could be variables omitted from the model but correlated with both the dependent and independent variables. After presenting the main results in the next section, we address these concerns by conducting a series of robustness checks, including a sensitivity analysis.

\section{Main Results}

In this section, we present evidence of the clear differences in complaint-making behavior between insiders and outsiders in both urban and rural areas. We also explore factors that may

\footnotetext{
${ }^{8}$ Logistic regression models with a large set of dummy variables can potentially suffer from the "incidental parameter" problem, namely, imprecise estimation of coefficients of dummy variables due to small numbers of observations in each city district or village will cause inconsistent estimates of the coefficients in interest. For that reason, in Online Appendix Table 2, we also use a linear probability model to check the robustness of our main finding. We find, however, that the results are very similar to the logistic models.
} 
contribute to these differences. Our data, though not conclusive, provides suggestive evidence that insiders complained more to authorities, not because they were more unsatisfied with public services, but because they had better information about government policies and procedures, better access to government officials, and more protection against potential political retribution.

In Table 1 and Table 2, we test for the relationship between political connections and the likelihood of complaining about local government performance. Table 1 reports the regression results based on the urban sample while Table 2 reports results from the rural sample. In both urban and rural areas, we find that insiders are much more likely to complain to government authorities even when controlling for demographic and socio-economic variables, as well as a full set of regional dummies.

In Table 1, using the urban sample, we control for the respondent's gender, age (level and squared terms), years of formal education, Communist Party membership, whether he or she is a government official, whether he or she holds a local, urban Hukou to capture the respondent's migration status, and dummies of city administrative districts. Standard errors clustered at the district level are reported in the parentheses. We find that having a relative working in the government is associated with roughly a 7 percentage point increase in the probability of complaining to the government using all possible measures the CPGS asked. More specifically, insiders were 3.5 percentage points more likely to complain about government performance by visiting a government office. The differences are sizable, given dependent variable means of 17.4, and 7.6 percentage points, respectively. OLS regressions give qualitatively the same results. ${ }^{9}$

The relationship between political connections and complaint making is substantively meaningful. It is 14 times of the effect of one additional year of education on complaint making.

\footnotetext{
${ }^{9}$ See Online Appendix Table 2.
} 
If we discretize the years of education variable into different level of education, the effect of political connections is 2 times the effect of a college degree or a high school education on complaint-making. The effect of political connections is huge given that the effect of education on political participation has been one of the most robust empirical findings in the political science literature.

\section{[TABLE 1 ABOUT HERE]}

The effect of political connections is also stronger than the effect of being a member of the CCP on complaint making, which is about 2.5 percentage points and not statistically significant. This comparison is important because Party membership remains a strong signal of one's human capital and social status in the Chinese labor market (Li, Liu, Zhang and Ma 2007). Many enterprises in China, including private ones, target Party members in the recruiting process and even make Party membership an implicit requirement for promotion, giving them significant economic and social advantages over non-Party members. At the same time, the fact that the importance of political connections and family ties now surpasses formal Party membership as a resource for participation may be an important indication of how much the work unit system and its institutional linkages to formal Party organizations have weakened.

For rural respondents, political connections are associated with significantly higher probabilities of complaining about local public goods provision to the village committee and to fellow villagers. The estimated coefficient of being politically connected on complaining to the village committee is 10.3 percentage points and significant at the 1 percent level when no control variables are added and becomes 7.9 percentage points and is still significant at the 1 percent level when the respondents' age (level and squared terms), gender, years of education, Communist Party membership, and village cadre status are included in the regression. The coefficient on complaining to fellow villagers is 7.4 percentage points and significant at the 5 percent level when 
the control variables are not included and decrease to 5.6 percentage points when the control variables are included, but still significant at the 5 percent level. Village fixed effects are always controlled for in all four regressions. Given that roughly 37 and 49 percent of villagers had complained to village authorities and other villagers, respectively, these effect sizes are substantively quite large. The association between political connections and complaint-making is equivalent to 7 years of formal education, or 3.2 times the effect of high school education and 1.3 times the effect of middle school education if we discretize the education variable.

\section{[TABLE 2 ABOUT HERE]}

The effect of Communist Party membership is much stronger in rural areas than in urban areas. Party members were in general more vocal than those who were merely politically connected. On average, villagers who were Party members were 20.7 percentage points more likely to complain about local public services to village authorities and 17.4 percentage points more likely to complain to fellow villagers. The stronger effect of Party membership may be due to the fact that in rural areas, there is much more institutional overlap between formal Party institutions and local administration than in urban areas so that Party members play a much bigger role in influencing decisions of the village authorities. It may also be because local public goods provision in rural China is far more decentralized and closer to citizens in the countryside than it is in urban China.

One may question whether these results merely reflect that insiders in urban and rural areas only care about their personal and family interests and use political connections to secure these interests. We find it unlikely. As mentioned above, in rural survey, we specifically asked about "public projects," projects that affect many; while the majority of the complaints were about public services, such as food safety and utilities in the urban areas (Figure 1(a)). Moreover, in the urban survey, we also asked those who had reportedly filed a complaint whether the complaint 
only concerned him/herself. Figure 1(b) shows that, according to their reports, insiders are actually less likely to complain about issues that only concern him/herself than outsiders (34\% vs. $41 \%$ ) and more likely to complain about issues that matter for almost everybody in the neighborhood (31\% vs. 22\%). These data thus present a different picture than earlier research (e.g. Michelson 2007a) suggesting that outsiders might come to resent insiders for being better able to pursue their personal interests.

\section{[FIGURE 1 ABOUT HERE]}

\section{Citizen satisfaction}

We consider two main explanations for why political connections lead to more complaining to authorities: (1) insiders could be more dissatisfied with the government and its public services than outsiders and (2) insiders could have more resources for making complaints. ${ }^{10}$

First, we assess whether insiders have higher levels of dissatisfaction. In the urban survey, respondents were asked to score on a scale from one to ten the following items: (1) their level of general happiness, (2) their level of satisfaction with their standard of living, and (3) their level of satisfaction towards various local public services, including education, health care, public utility, social security, etc. An overall measure of public service satisfaction rate was created by averaging scores on the 11 types of public services. ${ }^{11}$ In the rural survey, respondents were asked (1) if they were satisfied with the amount of effort members of the village committee and township government have put into providing public services and (2) if they were satisfied with different

\footnotetext{
${ }^{10}$ We also considered other channels, such as a citizen's civic skills (in terms of participating social activities) and civic virtue (in terms of willingness to express opinions on public affairs). These channels do not seem to be the main reasons why insiders complained more than outsiders. Controlling for related variables does not change our main results.

${ }^{11}$ The exact questions are: (1) "In general, do you feel happy about your life?" (2) "Are you satisfied with the living conditions of your family?" and (3) "Please score the following public services provided by the municipal government." The list of twelve public services enumerated in this question is provided in the Online Appendix. Heating is excluded when we take averages because it is not provided by the local governments in southern China, which includes half of the sample cities.
} 
kinds of public services, including roads, school, clinics, sanitation facilities, etc. As Online Appendix Table 1 shows, on average urban residents score roughly 7 points on a 1-10 scale on local public services while the average public service satisfaction rate among rural villagers is about 50 percent. We run OLS regressions controlling for the respondents' characteristics and regional fixed effects as in the logistic regression. The results are shown in Table 3.

Table 3 shows that after covariates and regional fixed effects are taken into account, those who are politically connected are not more unsatisfied with their lives or with the public services than ordinary citizens. If anything, it is the opposite. In rural areas, insiders were 19 percent more satisfied with performance of the village committee than outsiders. In urban areas, insiders were slightly more satisfied with the government than outsiders, but the difference is not statistically significant. At any rate, the proposition that insiders complained more to authorities than outsiders because simply they were more unsatisfied seems implausible.

\section{[TABLE 3 ABOUT HERE]}

One may wonder why a Chinese citizen with relatives in the government does not call up their relatives to help solve their problems directly — thus having in a lower chance of complaining through formal channels. The reason is simple. Although insiders may be able to engage in private contacts with officials on regular basis, it is unlikely that their connections are always in positions to address their everyday problems. Instead, we argue that these connections provide important resources, such as information and access, for insiders to complain effectively.

\section{Information and access}

We hypothesize that individuals with political connections complain more to authorities because they have more resources for taking action in contexts where risk and uncertainty are challenges. Even if a relative or friend does not have the power to resolve their complaint, an 
individual can ask that relative or friend to make inquiries and obtain the necessary information or introduction for them. Equipped with more knowledge of government decision makers and procedures, insiders may know more about how to complain effectively; and because they have better access to authorities, they may know more about where to file their complaints and feel less fearful about political reprisals.

In the urban survey, we measure respondents' political knowledge based on three variables: (1) whether they were able to get access to government documents or statutes; (2) whether they know the mayor or party secretary's name; and (3) whether they use email regularly_we assume that people who use email regularly were more proficient in modern information technology and thus better able to locate useful information. In the rural survey, we measure the respondents' political knowledge by asking (1) whether they know the township head's name, (2) whether they know the provincial governor or party secretary's names, and (3) whether they read newspapers.

[FIGURE 2 ABOUT HERE]

We apply the same model in the regression analysis with the full set of control variables. Figure 2 presents the results (corresponding regression tables are shown in Online Appendix Tables 5-7). The upper panel of Figure 2 shows that in both urban and rural areas, insiders had much better political knowledge than outsiders. In the urban area, insiders are 4.5 percentage points more likely to report that they were able to find government documents or statutes, if they need to, than outsiders. They were also more likely to know the mayor or party secretary's name and to use emails regularly. In rural areas, insiders were 12.4 and 4.3 percentage points more likely to know the township head's name and the provincial governor's name, respectively. Insiders were also more likely to read newspapers than outsiders. Note that controls for the respondents' level of education and Party membership are already included. 
To measure respondents' access to government or government authorities in the urban survey, we asked the following three questions: (1) whether the respondent had used connections to secure preferential government services, such public education and health care - which was a separate question and clearly distinguished for respondents from our outcome measure; (2) whether the respondent had recently dealt with the government (与政府打交道); and (3) whether the respondent had attempted to "pull strings" (拉关系) when dealing with the government. As the lower panel of Figure 2 shows, insiders were more likely than to have used their connections to obtain preferential access to public services, recently dealt with the government, and "pulled strings." All three coefficients are large in magnitude and statistically significant at the 1 percent level. $^{12}$

In the rural survey, we do not have measures of the respondents' perceived access to government or government authorities. However, the survey asked villagers questions about their perceptions of external efficacy, i.e. whether they thought village authorities welcomed them to express views on public policies and whether they perceived that particular levels of government welcomed villagers to issue their complaints. We find that insiders were more likely to have higher perceptions of external efficacy; insiders were 11 percentage points more likely to agree that cadres allowed villagers to express views than outsiders. This is not that surprising since they are, after all, family members of village or government authorities. What is more interesting is the diminishing differences between insiders and outsiders when they were asked whether a certain level of government welcomed complaints as the level the government moves up. For example, insiders were 8.1 percentage points more likely to agree on the statement that the township government welcomed complaints than outsiders; however, the difference became almost non-

\footnotetext{
${ }^{12}$ In Table 8 in Online Appendix, we also show that insiders perceived more misconduct and malfeasance of officials than outsiders. This is likely because they simply had more interactions with government officials. Controlling for the respondents' perception of the government does not change our main findings.
} 
existent when they were asked about the central government (Online Appendix Table 7). Also note that on average villagers see the higher levels of government as more receptive than the lower levels, which is consistent with findings from previous studies (e.g. Li 2004). The evidence presented in Figure 2 suggests that insiders have a much closer relationship with the local government than outsiders. But in the context of rural China, it is precisely the lower level government — village authorities and the township government — that are in charge of providing local public services.

In this section, we have presented evidence that, in both rural and urban China, insiders have a much higher probability of filing complaints about government services to authorities than outsiders. We show that insiders are equipped with better information and have better access to the government than outsiders. Insiders are not, however, more dissatisfied with the government or its services. We also find that the variables representing access to authorities explains a large chunk of the difference in the urban area while the variables representing political knowledge and information explain much of the difference in the rural area. These findings, though suggestive, are broadly consistent with our theory presented in the previous sections.

\section{Robustness Checks}

In this section, we conduct several robustness checks to show that the strong associations between political connections and citizens' complaint-making behavior we previously found are not driven by particular modeling assumptions or potential omitted variables. Therefore, it is very likely that having political connections has a causal effect on a person's probability of making a complaint about public services to authorities.

First, we use matching methods to show that our finding does not rely on a linear and additive parametric model. Even when we compare respondents of the same gender, roughly the 
same age, the same education level, and, perhaps most importantly, within the same geographic area (an urban district or a rural village), we find that insiders were much more likely to file complaints to authorities than outsiders. Second, to address concerns that a person's propensity to trust others, his or her occupation and family wealth may be driving the observed relationship, we explicitly control for these variables - despite the fact that these variables can be outcomes of political connection - and show that our main results remain unchanged. Third, we conduct a sensitivity analysis to gauge the likelihood of potential confounding variables causing the observed associations. We show that, for instance, even if there exists an unobserved uncontrolled factor that is correlated with both political connections and people's propensity to participate, it is extremely implausible for such an omitted variable to explain fully the strong association between political connections and complaint making.

\section{Relaxing model dependency—matching methods}

We have mentioned that our main results remain almost unchanged when we use a linear probability model instead of logistic regressions. In this subsection, we use non-parametric matching methods to illustrate further that our findings are not subject to strong modeling assumptions. We employ both exact matching and non-exact matching methods. In both urban and rural samples, we attempt to find comparable respondents who did not have connections for those who have connections and estimate the average treatment effect on the treated (ATT), namely, the average effect of being politically connected on those who were actually connected (or insiders). In the urban and rural samples, the outcome variables are complaining to the government and complaining to the village committee, respectively.

[TABLE 4 ABOUT HeRE] 
With exact matching, insiders are paired with outsiders with the same gender, roughly the same age, ${ }^{13}$ the same level of education, the same party affiliation (a Communist Party member or not), the same status as government or village authority, for the urban sample the same urban Hukou status, and, most importantly, residence in the same locality. With non-exact matching, insiders and outsiders in the same locality are matched based on their Mahalanobis distance of the above covariates from each other. In other words, even with non-exact matching, we compare insiders and outsiders within the same geographic cluster. We try four different numbers of matched pairs for each connected respondent: $\mathrm{M}=1,2,4$, and 8 . When $\mathrm{M}=2$, for instance, each insider is matched with two outsiders that are "closest" to him or her in the values of the covariates. The standard bias correction method is employed for all non-exact matching estimates. The results are shown in Table 4.

We find that using the urban sample, the estimates of political connections are always large, positive, and highly significant, no matter which method we use or how many outsider respondents we attempt to match with each insider respondent. The estimated effect of political connections is around 5-7 percentage points, about the same as those reported in Table 1, and highly statistically significant. Applying the matching methods to the rural sample, we find that the estimated ATTs of political connections are about 4-7 percentage points, which are also similar to we obtain from the regression analysis (Table 2), and are always statistically significant.

In general, we find that the results from matching methods are similar to the baseline finding using regressions. In other words, our main finding remains intact when we relax the linear assumption in modeling the probability of complaint making.

\footnotetext{
${ }^{13}$ In the urban sample, we split the sample into four age bins: 18-30, 31-40, 41-50, and 51-60. In the rural sample, the four age bins are 16-40, 41-50, 51-60, and 61-87. We ensured that the numbers of observations in each age bin are roughly the same in each of sub-samples.
} 


\section{Additional controls and sensitivity analysis}

We now address the concern of potential omitted variables. In the baseline specifications, we do not include measures of the respondents' propensity to trust others, their family wealth, and occupations because these variables may be results of a person's political connections. Including these "post-treatment" variables may lead to an underestimation of the effect of political connection (Angrist and Pischke 2009). It is, however, possible that these variables foster a person's political connections and at the same time contribute to a higher level of political participation. For example, a person with a decent, high-paying job is more likely to be able to secure a government job for his or her children or marry another person who works in the government. Therefore, we add measures of social trust, family wealth, and an indicator of occupation to the full multivariate models to test the robustness of our main findings. ${ }^{14}$ The estimated marginal effects of political connections when these variables are included can serve as the lower bound of the true coefficient if the baseline model is correctly specified and there are no other omitted variables. The results in presented in the Online Appendix, which show that, in both urban and rural areas, the strong associations between political connections and complaint making are robust to controlling for these variables.

However, there could still be concerns that some important confounding variables, variables that are correlated with both the dependent and independent variables but have not been controlled for, are left unobserved, and hence not included in the model. To address these concerns, we conduct a sensitivity analysis to show that our main findings are not sensitive to potential unobserved confounders. The basic idea of a sensitivity analysis is to show the extent to which an unobserved potential confounder needs to be correlated with both the treatment and

\footnotetext{
${ }^{14}$ We use two hypothetical questions to measure trust in urban and rural surveys (see Online Appendix for details).
} 
outcome variables in order to fully explain the observed treatment effect or render the treatment effect statistically insignificant. ${ }^{15}$

To implement the sensitivity analysis, we place potential confounding variables in a twodimensional space. The $\mathrm{x}$-axis is the partial correlation between a hypothetical confounder and the outcome variable (complaint making) while the y-axis is the partial correlation between the treatment variable (having political connections) and the confounder. ${ }^{16}$ We then draw a contour line such that a confounding variable on or beyond the line (on the top-right corner) would render the observed treatment effect insignificant. In other words, any point located at bottom-left to the threshold line represents a confounder that is unable to eliminate the statistical significance of the effect of political connections on complaint making.

For the purpose of comparability, we show the confounding effect of each of the observed control variables had it not been observed and hence not controlled for. Because these control variables are what we believe to be most likely ones confounding the relationship between political connections and complaint making, if they all pass the test, the likelihood that a confounder that is strong enough to eliminate all the significant result is small.

We first conduct a sensitivity analysis based on the urban sample. Again, the independent variable is being politically connected and the dependent variable is complaining to the government using all possible measures. The result is presented in Figure 3(a). The red dashed contour line is the threshold line. Any point on or beyond the line would render the observed treatment effect of political connections insignificant at the 5\% level. We see from Figure 3(a) that all observed control variables, including Communist Party membership and college or high

\footnotetext{
${ }^{15}$ For a detailed explanation of the application of sensitivity analyses in program evaluation, see Imbens (2003). Hazlett (2015) provides a good example in political science.

${ }^{16}$ The partial correlations would be obtained by regressing the outcome variable on the unobserved confounders and the covariates, and by regressing the unobserved confounder on the treatment and the covariates, respectively.
} 
school education, are far beneath the threshold line. This means that, compared with observed covariates, an unobserved confounder needs to be much more strongly correlated with both the dependent and independent variables to make the effect of political connections insignificant, which seems highly unlikely.

\section{[FIGURE 3 ABOUT HERE]}

A similar analysis was conducted based on the rural sample. The independent variable is having political connections and the dependent variable is complaining to the village authorities. The result is presented in Figure 3(b). Again, the threshold line is the red dashed line. We see that, even if a confounder is twice as strongly correlated with both the dependent and independent variables as Communist Party membership or village cadre status, controlling for it would not make the statistical significance (at the 5 percent level) of the coefficient of political connections go away. In the context of the Chinese countryside, it is hard to imagine a variable that is much more strongly correlated with political connections than being a Party member or a village cadre and strongly correlated with villagers' complaint-making behavior as well.

In summary, the results from the sensitivity analyses suggest that it is very unlikely that the strong associations between political connections and complaint making in either urban or rural areas are driven by unobserved potential confounding variables. It is thus highly plausible that having political connections leads to an increase in the probability of filing complaints to authorities in both urban and rural areas.

\section{Concluding remarks}

When do individuals in transitional systems and developing democracies who want to complain about governmental performance have the resources to do so? By refining the existing resource mobilization model of political participation, this paper contributes to our theoretical and 
empirical understanding of citizen participation in nondemocratic and transitional systems. Commonly accepted resources such as income and education can indeed enable individuals in a variety of contexts to take political action. But in contexts where there is limited government transparency and/or some political risk, personal connections to authorities can be an important resource for making complaints about governmental performance. At least when it comes to expressing criticisms of governmental performance on an individual basis, people with personal connections to authorities are better positioned than people who lack any connections. They have better access to authorities, more information about how the system works, and/or a greater degree of political protection.

These findings argue for a more nuanced understanding of the roles that political connections play in transitional systems and developing democracies. Most of the literature in political science focuses on the ways in which personal relationships help elites mobilize individuals for top-down objectives, while at times enabling individuals to obtain particularistic benefits. Political connections are undoubtedly important for these reasons, but we suggest that these relationships can also act as a resource for civic, autonomous, and bottom-up political action.

Relatedly, these findings suggest that we need to rethink our assumptions about political intermediaries and brokers, and re-conceptualize them as multifaceted political actors.

Intermediaries and brokers do not always simply funnel clientelistic goods from governments and political parties to individuals in exchange for votes and political support. They can also act as political guides, advisors, and protectors to those in their networks who seek to provide input on government performance and public goods provision. We should thus be investigating the conditions under which intermediaries more likely to serve one purpose rather than another, whether certain types of intermediaries are more likely to specialize in a particular function, and 
whether different types of interactions with intermediaries affect the attitudes and expectations that individuals have about the government.

Highlighting the importance of political connections as a participatory resource also has implications for evaluating representation and whose voice is heard on issues that concern the public interest. If we define the politically well-resourced simply as those who have more money or education, and look only at differences in policy priorities between rich and poor, or more and less educated, we may draw the wrong conclusions about whose voices are being heard by decision makers, what input they are taking into account, or how responsive or unresponsive they are being to the input they are hearing. We may, for example, know that the educated have certain policy preferences, and we may see that policy decisions do not reflect these preferences. If we assume that education is the most important resource for participation, then we might conclude that the government is not responsive to citizen input. If, however, political connections are the most important resource for voice, and those who are politically connected are not necessary those who are well educated, then it might be that the government is responsive to the voices it hears but that these voices are those of the politically connected, not the educated.

Questions of representation and government responsiveness are of interest not just in consolidated democracies - but also in developing democracies and transitional systems because they can have implications for theories of authoritarian durability. If the authorities hear complaints disproportionately from those with political connections, inequality of voice and representation may not matter if those with political connections have the same kinds of complaints as those without connections. In this case, those with connections simply represent complaints by the general population. The unequal distribution of resources for participation between insiders and outsiders could become problematic, however, if outsiders differ significantly in the substance of their complaints. It may be, for example, that the nature of 
complaints by outsiders more easily lend themselves to protest rather than through officially sanctioned channels. If authorities only hear - and to the extent that they choose to do so respond to input from a select minority of insiders, it is possible that the resource gap in participation may lead to deeper fissures in state-society relations.

Finally, this research has implications for our understanding of how autocrats maintain regime stability. Political order, as Huntington argued, is best sustained when existing formal institutions moderate and channel citizen participation and feedback so that it is kept inside the political system (Huntington 1968). The worst possible scenario is when high levels of dissatisfaction and participation from the populace at large overwhelm the formal channels. It is thus essential to understand who uses formal channels for feedback to the regime, and who they are. In political systems where the people who are more likely to provide feedback are those who have personal connections to authorities and who are perhaps more personally invested in the regime, feedback may more likely to be constructive and less likely to overwhelm the system. 


\section{Tables}

TABLE 1: CONNECTIONS AND COMPLAINT-MAKING: URBAN RESIDENTS

\begin{tabular}{|c|c|c|c|c|}
\hline \multirow[t]{2}{*}{ Dependent Variables } & \multicolumn{2}{|c|}{$\begin{array}{c}\text { Complain to the } \\
\text { Government }\end{array}$} & \multicolumn{2}{|c|}{$\begin{array}{c}\text { Complain through } \\
\text { Government Offices }\end{array}$} \\
\hline & $(1)$ & $(2)$ & (3) & $(4)$ \\
\hline Political Connections & $\begin{array}{c}0.070 * * * \\
(0.014)\end{array}$ & $\begin{array}{c}0.071 * * * \\
(0.015)\end{array}$ & $\begin{array}{c}0.035 * * * \\
(0.013)\end{array}$ & $\begin{array}{l}0.031 * * \\
(0.014)\end{array}$ \\
\hline Years of Education & & $\begin{array}{c}0.005 * * \\
(0.002)\end{array}$ & & $\begin{array}{c}0.003 \\
(0.002)\end{array}$ \\
\hline Communist Party Member & & $\begin{array}{c}0.025 \\
(0.020)\end{array}$ & & $\begin{array}{l}-0.013 \\
(0.023)\end{array}$ \\
\hline Government Official & & $\begin{array}{l}-0.049 \\
(0.030)\end{array}$ & & $\begin{array}{l}-0.255 \\
(0.032)\end{array}$ \\
\hline Age/10 & & $\begin{array}{c}0.050 \\
(0.033)\end{array}$ & & $\begin{array}{c}0.024 \\
(0.034)\end{array}$ \\
\hline Age-squared/100 & & $\begin{array}{l}-0.005 \\
(0.004)\end{array}$ & & $\begin{array}{l}-0.001 \\
(0.004)\end{array}$ \\
\hline Male & & $\begin{array}{c}0.010 \\
(0.010)\end{array}$ & & $\begin{array}{l}-0.003 \\
(0.011)\end{array}$ \\
\hline Urban Hukou & & $\begin{array}{l}-0.011 \\
(0.018)\end{array}$ & & $\begin{array}{c}0.000 \\
(0.017)\end{array}$ \\
\hline Dependent Variable Mean & 0.174 & 0.173 & 0.076 & 0.078 \\
\hline District Dummies & $\mathrm{X}$ & X & $\mathrm{X}$ & $\mathrm{X}$ \\
\hline Number of Districts & 128 & 125 & 70 & 69 \\
\hline Number of Observations & 5,406 & 5,182 & 3,113 & 2,974 \\
\hline Pseudo R-squared & 0.189 & 0.196 & 0.164 & 0.171 \\
\hline
\end{tabular}

Notes: This table reports the marginal effects of the independent variables at sample means, estimated by a logistic model. Standard errors clustered by city administrative district are in the parentheses. District fixed effects are controlled for in all the regressions. The loss of observations in Columns (3)-(4) is mainly due to the fact that there is no variation (i.e., all zeroes) of the outcome variable in many districts. The conditional logit model drops these observations automatically. Level of statistical significance: $* * * p<0.01, * * p<0.05, * p<0.1$. 
TABle 2: CONNECTIONS AND COMPLAINT-MAKING: RURAL VILLAGERS

\begin{tabular}{|c|c|c|c|c|}
\hline \multirow[t]{2}{*}{ Dependent Variables } & \multicolumn{2}{|c|}{$\begin{array}{l}\text { Complain to the Village } \\
\text { Committee }\end{array}$} & \multicolumn{2}{|c|}{$\begin{array}{c}\text { Complain to Fellow } \\
\text { Villagers }\end{array}$} \\
\hline & $(1)$ & $(2)$ & (3) & $(4)$ \\
\hline Political Connections & $\begin{array}{l}0.103 * * * \\
(0.027)\end{array}$ & $\begin{array}{c}0.079 * * \\
(0.027)\end{array}$ & $\begin{array}{c}0.074 * * \\
(0.028)\end{array}$ & $\begin{array}{c}0.056^{* *} \\
(0.028)\end{array}$ \\
\hline Years of Education & & $\begin{array}{c}0.011 * * * \\
(0.004)\end{array}$ & & $\begin{array}{c}0.010 * * \\
(0.004)\end{array}$ \\
\hline Communist Party Member & & $\begin{array}{c}0.207 * * * \\
(0.033)\end{array}$ & & $\begin{array}{c}0.174 * * * \\
(0.038)\end{array}$ \\
\hline Village Cadre & & $\begin{array}{c}0.163 * * * \\
(0.035)\end{array}$ & & $\begin{array}{c}0.104 * * * \\
(0.041)\end{array}$ \\
\hline Age/10 & & $\begin{array}{c}0.054 \\
(0.065)\end{array}$ & & $\begin{array}{l}-0.039 \\
(0.075)\end{array}$ \\
\hline Age-squared/100 & & $\begin{array}{l}-0.005 \\
(0.006)\end{array}$ & & $\begin{array}{c}0.002 \\
(0.007)\end{array}$ \\
\hline Male & & $\begin{array}{c}0.067 * * * \\
(0.024)\end{array}$ & & $\begin{array}{c}0.043 \\
(0.027)\end{array}$ \\
\hline Dependent Variable Mean & 0.373 & 0.373 & 0.491 & 0.491 \\
\hline Village Dummies & X & X & X & $\mathrm{X}$ \\
\hline Number of Villages & 101 & 101 & 101 & 101 \\
\hline Number of Observations & 1,980 & 1,967 & 1,984 & 1,960 \\
\hline Pseudo R-squared & 0.131 & 0.160 & 0.070 & 0.098 \\
\hline
\end{tabular}

Notes: This table reports the marginal effects of the independent variables at sample means, estimated by a logistic model. Standard errors clustered by village are in the parentheses. Village fixed effects are controlled for in all the regressions. Level of statistical significance: $* * * \mathrm{p}<0.01, * * \mathrm{p}<0.05,{ }^{*} \mathrm{p}<0.1$. 
TABLE 3: CoNNECTIONS AND CITIZEN SATISFACTION

\begin{tabular}{|c|c|c|c|c|c|c|}
\hline \multirow[b]{2}{*}{ Dependent Variables } & \multicolumn{3}{|c|}{ Urban } & \multicolumn{3}{|c|}{ Rural } \\
\hline & $\begin{array}{c}\text { General } \\
\text { Happiness } \\
\text { about Life } \\
\text { (scale 1-10) } \\
(1)\end{array}$ & $\begin{array}{l}\text { Satisfaction } \\
\text { with } \\
\text { Standard of } \\
\text { Living } \\
\text { (scale 1-10) } \\
(2) \\
\end{array}$ & $\begin{array}{c}\text { Satisfaction } \\
\text { towards } \\
\text { Local } \\
\text { Public } \\
\text { Services } \\
\text { (scale 1-10) } \\
(3) \\
\end{array}$ & $\begin{array}{c}\text { Satisfaction } \\
\text { towards the } \\
\text { Village } \\
\text { Committee } \\
(4)\end{array}$ & $\begin{array}{c}\text { Satisfaction } \\
\text { towards the } \\
\text { Township } \\
\text { Government } \\
(5)\end{array}$ & $\begin{array}{c}\text { Satisfaction } \\
\text { towards } \\
\text { Public } \\
\text { Services } \\
(6) \\
\end{array}$ \\
\hline Political Connections & $\begin{array}{c}0.052 \\
(0.081)\end{array}$ & $\begin{array}{c}0.114 \\
(0.077)\end{array}$ & $\begin{array}{c}0.103 \\
(0.075)\end{array}$ & $\begin{array}{c}0.185 * * * \\
(0.044)\end{array}$ & $\begin{array}{c}0.083 \\
(0.059)\end{array}$ & $\begin{array}{c}0.020 \\
(0.012)\end{array}$ \\
\hline Dependent Variable Mean & 7.704 & 7.321 & 7.034 & 2.70 & 2.46 & 0.504 \\
\hline District/Villages Dummies & $\mathrm{X}$ & $\mathrm{X}$ & $\mathrm{X}$ & $\mathrm{X}$ & $\mathrm{X}$ & $\mathrm{X}$ \\
\hline R-squared & 0.226 & 0.229 & 0.340 & 0.205 & 0.155 & 0.286 \\
\hline
\end{tabular}




\section{TABLE 4: CONNECTIONS AND COMPLAINT-MAKING: MATCHING METHODS}

\begin{tabular}{|c|c|c|c|c|c|}
\hline \multirow[t]{3}{*}{ Urban } & \multicolumn{5}{|c|}{ Complain to the Government } \\
\hline & \multirow{2}{*}{$\begin{array}{c}\text { Exact } \\
\text { Matching } \\
(1)\end{array}$} & \multicolumn{4}{|c|}{ Non-exact Matching } \\
\hline & & $\begin{array}{c}M=1 \\
(2)\end{array}$ & $\begin{array}{c}\mathrm{M}=2 \\
(3)\end{array}$ & $\begin{array}{c}\mathrm{M}=4 \\
(4)\end{array}$ & $\begin{array}{c}M=8 \\
(5)\end{array}$ \\
\hline Political Connections & $\begin{array}{c}0.061 * * * \\
(0.014) \\
{[340]} \\
\end{array}$ & $\begin{array}{c}0.048^{* *} \\
(0.025) \\
{[711]} \\
\end{array}$ & $\begin{array}{c}0.064 * * * \\
(0.023) \\
{[711]} \\
\end{array}$ & $\begin{array}{c}0.071 * * * \\
(0.019) \\
{[699]} \\
\end{array}$ & $\begin{array}{c}0.066 * * * \\
(0.018) \\
{[699]} \\
\end{array}$ \\
\hline \multirow[t]{3}{*}{ Rural } & \multicolumn{5}{|c|}{ Complain to the Village Committee } \\
\hline & \multirow{2}{*}{$\begin{array}{c}\text { Exact } \\
\text { Matching } \\
(1)\end{array}$} & \multicolumn{4}{|c|}{ Non-exact Matching } \\
\hline & & $\begin{array}{c}M=1 \\
(2)\end{array}$ & $\begin{array}{c}\mathrm{M}=2 \\
(3)\end{array}$ & $\begin{array}{c}\mathrm{M}=4 \\
(4)\end{array}$ & $\begin{array}{c}M=8 \\
(5)\end{array}$ \\
\hline Political Connections & $\begin{array}{c}0.050^{* * *} \\
(0.016) \\
{[109]}\end{array}$ & $\begin{array}{c}0.055^{*} \\
(0.033) \\
{[421]}\end{array}$ & $\begin{array}{c}0.042 \\
(0.031) \\
{[421]}\end{array}$ & $\begin{array}{c}0.074 * * * \\
(0.029) \\
{[421]}\end{array}$ & $\begin{array}{c}0.074 * * * \\
(0.028) \\
{[421]}\end{array}$ \\
\hline \multicolumn{6}{|c|}{$\begin{array}{l}\text { Notes: This table presents the results from matching methods. Each coefficient represents the average treatment } \\
\text { effect on the treated (ATT) of political connections. The matching methods are based on the following set of } \\
\text { covariates: the respondent's age, gender, years of education, Communist party membership, government official or } \\
\text { village cadre status, urban Hukou status (for the urban sample), and district or village dummies. In column (1), the } \\
\text { exact matching method is employed while in columns (2)-(5), non-exact matching methods (with bias-correction) } \\
\text { of specified number of matches for each treated unit (M) are used. Robust standard errors are in the parentheses. } \\
\text { In the brackets are the numbers of matched pairs. Level of statistical significance: } * * * \text { p }<0.01, * * \text { p }<0.05 \text {, } \\
\text { p }<0.1 \text {. }\end{array}$} \\
\hline
\end{tabular}




\section{Figures}

\section{FIGURE 1: COMPLAINTS BY URBAN RESIDENTS}

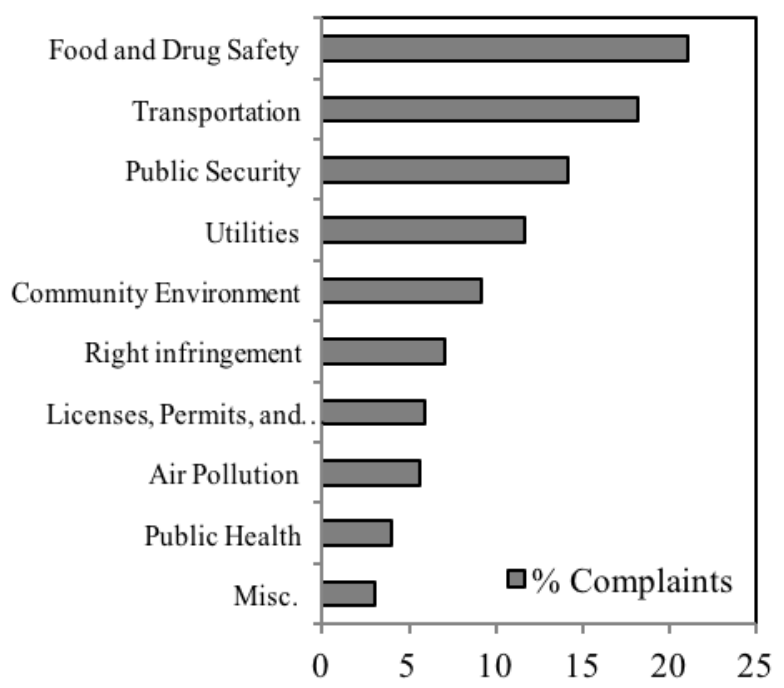

Note: The denominator is the total number of complaints reported by the respondents.

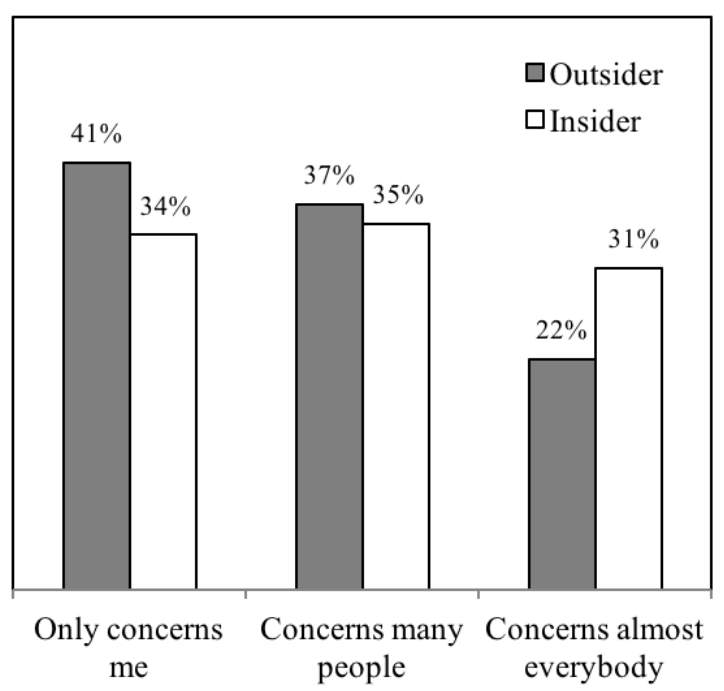

Note: Based on the following question: "Did your complaint only concern yourself?" Respondents who had reportedly filed a complaint were asked this question.

(b) Civic versus Private Interests

(a) Issues

FiguRE 2: MECHANISMS
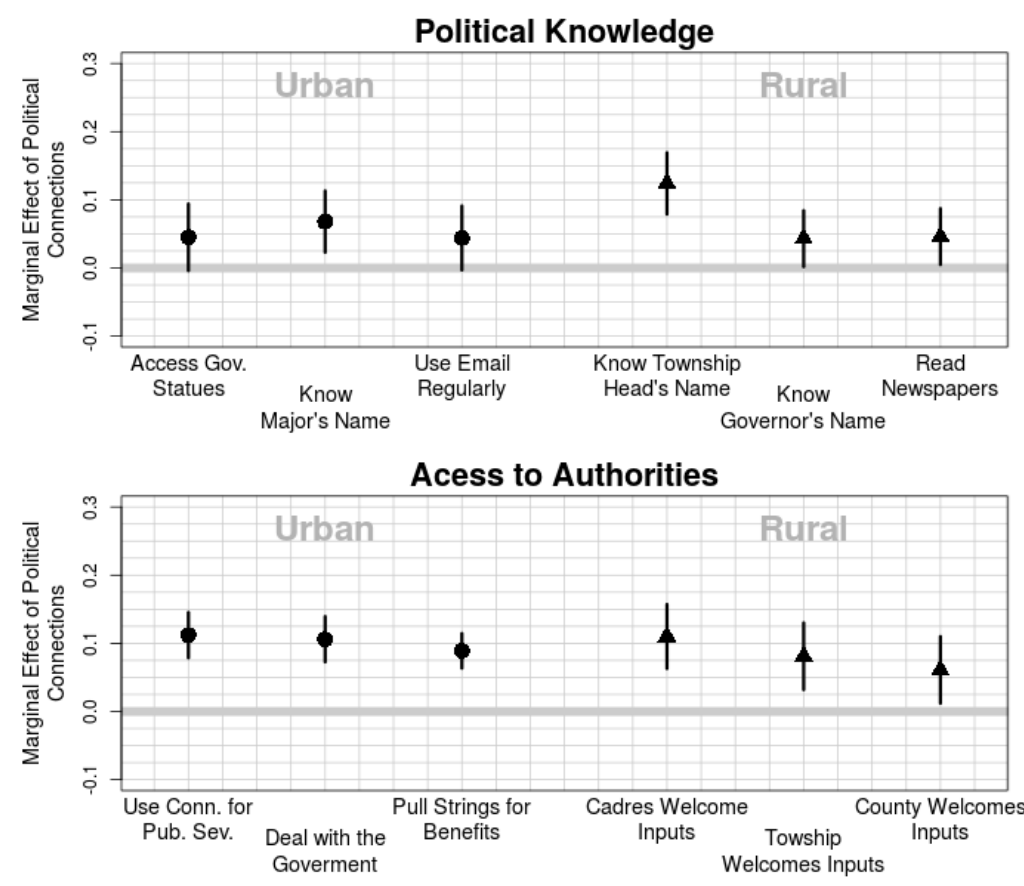
Figure 3: Sensitivity Analysis On the Effect of Political Connections

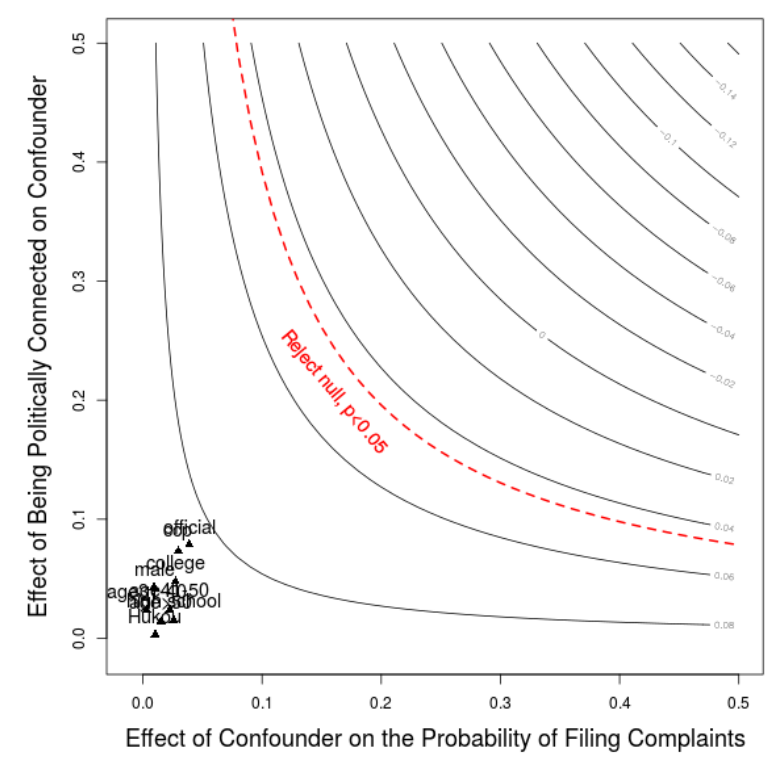

(a) Urban

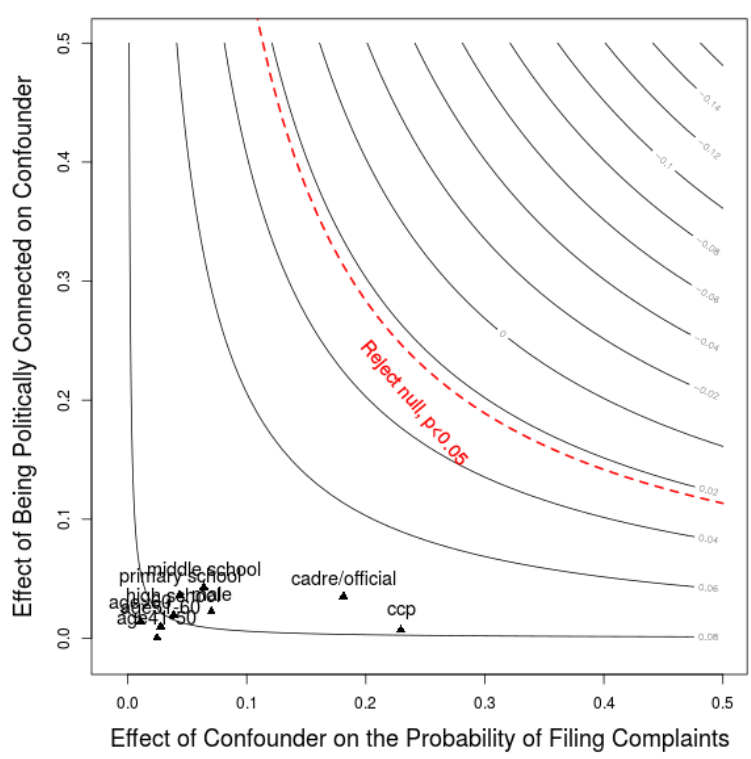

(b) Rural

\section{Compliance with Ethical Standards}

Conflict of Interest: The authors declare that they have no conflict of interest.

Ethical approval: All procedures performed in studies involving human participants were in accordance with the ethical standards of the institutional and/or national research committee and with the 1964 Helsinki declaration and its later amendments of comparable ethical standards.

\section{Acknowledgement}

We are grateful for the comments provided by Jean C. Oi, Yuen Yuen Ang, Erik H. Wang, the participants of workshops at the Center for Democracy, Development, and the Rule of Law at Stanford University and the Annual Meeting of the Midwest Political Science Association. We are also grateful to the anonymous referees and the editors of Political Behavior. Thanks to My 
Seppo and Blair Read for valuable editorial assistance. The authors bear sole responsibility for any errors. The China Public Governance Survey (CPGS) was conducted by Unirule Institute of Economics, a Beijing based think-tank, and HorizonKey, a survey company. The China Rural Governance Survey (CRGS) was conducted by the Center for Chinese Agricultural Policy in the Chinese Academy of Sciences. The authors appreciate the assistance of these organizations in providing the data. The views expressed in this paper, however, are the authors' own.

\section{References}

Amore, M. D., and Bennedsen, M. (2013). The value of local political connections in a lowcorruption environment. Journal of Financial Economics, 110, 387-402.

Ang, Y. Y., and Jia, N. (2014). Perverse complementarity: Political connections and the use of courts among private firms in China. The Journal of Politics, 76, 318-382.

Angrist, J. D., and Pischke, J-S. (2009). Mostly harmless econometrics: An empiricist's companion. Princeton, NJ: Princeton University Press.

Banfield, E. (1967). Moral basis of a backward society. New York, NY: Simon and Schuster, Inc.

Baviskar, A. (2010). Winning the right to information in India: Is knowledge power? In J. Gaventa and R. McGee (Eds.), Citizen action and national policy reform: Making change happen (Claiming citizenship: Rights, participation, and accountability) (pp. 130-152). London: Zed Books.

Besley, T. J., Pande, R., and Rao, V. (2007). Just rewards? Local politics and public resource allocation in South India. London, UK: London School of Economics.

Boone, C. (2003). Decentralization as political strategy in West Africa. Comparative Political Studies, 36, 355-380.

Botero, J., Ponce, A., and Shleifer, A. (2013). Education, complaints, and accountability. Journal of Law and Economics, 56(4), 959-996.

Bratton, M. (1994). Peasant-state relations in post-colonial Africa: Engagement or disengagement? In J. Migdal (Ed.), The state in society: Struggles and accommodation (pp. 231-254). Cambridge: Cambridge University Press. 
Carter, B. (2013). Evidence on budget accountability and participation. Birmingham, UK: Governance and Social Development Resource Centre (GSDRC).

Chandra, K. (2004). Why ethnic parties succeed. Cambridge: Cambridge University Press.

Chandra, K. (Ed.), (2012). Constructivist theories of ethnic politics. New York, NY: Oxford University Press.

Chatterjee, P. (2004). The politics of the governed: Reflections on popular politics in most of the world. New York, NY: Columbia University Press.

Chen, X. (2012). Social protest and contentious authoritarian China. Cambridge: Cambridge University Press.

Chen, J., Pan, J., and Xu, Y. (2016). Sources of authoritarian responsiveness: A field experiment in China. American Journal of Political Science, 60, 383-400.

Chen, J. and Xu, Y. (2015). Information Manipulation and Reform in Authoritarian Regimes. Political Science Research and Methods. https://doi.org/10.1017/psrm.2015.21.

Chen, J. and Xu, Y. (2016). Why Do Authoritarian Regimes Allow Citizens to Voice Opinions Publicly? The Journal of Politics, forthcoming.

Chirot, D. (Ed.), (1991). The crisis of Leninism and the decline of the left: The revolutions of 1989. Seattle, WA: University of Washington Press.

Corbridge, S., and Kumar, S. (2002). Community, corruption, landscape: Tales from the tree trade. Political Geography, 21, 765-788.

Dimitrov, M.(2013). Why communism did not collapse: Understanding authoritarian regime resilience in Asia and Europe. New York, NY: Cambridge University Press.

Fairbairn, M. (2013). Indirect dispossession: Domestic power imbalances and foreign access to land in Mozambique. Development and Change, 44(2), 335-356.

Fisman, R. (2001). Estimating the value of political connections. American Economic Review, 91(4), 1095-1102.

Folscher, A. (2010). Budget transparency: New frontiers in transparency and accountability. Transparency and Accountability Initiative. http://www.transparencyinitiative.org/reports/new-frontiers-in-transparency-and-accountability. Accessed 5 July 2016.

Freedom House (2015). Freedom in the world 2015. Washington, DC: Freedom House.

Fuller, C. J., and Benei, V. (Eds.). (2000). The everyday state and society in modern India. New Delhi: Social Sciences Press. 
Gerber, A., and Green, D. (2000). The effects of canvassing, telephone calls, and direct mail on voter turnout: A field experiment. American Political Science Review, 94, 653-663.

Gerber, A., Green, D., and Larimer, C. W. (2008). Social pressure and voter turnout: Evidence from a large-scale field experiment. American Political Science Review, 102(1), 33-48.

Ghertner, D. A. (2011). Gentrifying the state, gentrifying participation: Elite governance programs in Delhi. International Journal of Urban and Regional Research, 35(3), 504-532.

Givens, J. (2011) “Advocates of Change in Authoritarian Regimes: How Chinese Lawyers and Chinese and Russian Journalists Stay Out of Trouble." Available at SSRN: https://goo.gl/j05Y55.

Gold, T., Guthrie, D., and Wank, D. (Eds.), (2002). Social connections in China: Institutions, culture, and the changing nature of Guanxi. Cambridge: Cambridge University Press.

Goldman, E., Rocholl, J., So, J. (2013). Political connections and the allocation of procurement contracts. Review of Finance, 13(5), 1617-1648.

Goldstone, J. (1982). The comparative and historical study of revolutions. Annual Review of Sociology, 8, 187-207.

Granovetter, M. S. (1973). The strength of weak ties. American Journal of Sociology, 78, 13601380.

Guo, G. (2007). Organizational involvement and political participation in China. Comparative Political Studies, 40, 457-482.

He, B., and Warren, M. E. (2011). Authoritarian deliberation: The deliberative turn in Chinese political development. Perspectives on Politics, 9, 269-289.

Hofmann, A. (2006). El servicio profesional de carrera y su marcha hacia el final del sexenio [The professional career service and its progress toward the end of the current presidency]. Servicio Profesional de Carrera, 3, 21-41.

Huntington, S. (1968). Political Order in changing societies. New Haven, CT: Yale University Press.

Imbens, G. (2003). Sensitivity to exogeneity assumptions in program evaluation. American Economic Review, 93(2), 126-132.

Institute of Development Studies (2010). An upside-down view of governance. Brighton, UK: Institute of Development Studies.

Jenkins, R. (2007). Civil society versus corruption. Journal of Democracy, 18, 55-69.

Jennings, M. K. (1997). Political participation in the Chinese countryside. American Political Science Review, 91, 361-372. 
Johnson, S., and Mitton, T. (2003). Cronyism and capital controls: Evidence from Malaysia. Journal of Financial Economics, 67, 351-382.

Khagram, S., Fung, A., \& de Renzio, P. (2013). Open budgets: The political economy of transparency, participation, and accountability. Washington, DC: Brookings Institution Press.

Khanna, J., and Johnston, M. (2007). India's middlemen: Connecting by corrupting? Crime, Law, and Social Change, 40, 151-168.

Khwaja, A. I., and Mian, A. (2005). Do lenders favor politically connected firms? Rent provision in an emerging financial market. The Quarterly Journal of Economics, 120(4), 1371-1411.

Kitschelt, H., and Wilkinson, S. I. (Eds.), (2007). Patrons, clients, and policies. Cambridge: Cambridge University Press.

Knight, J., and Johnson, J. (2007). The priority of democracy: A pragmatist approach to politicaleconomic institutions and the burden of justification. American Political Science Review, 101(1), 47-61.

Korte, C., and Milgram, S. (1970). Acquaintance networks between racial groups. Journal of Personality and Social Psychology, 15, 101-108.

Krishna, A. (2002). Enhancing political participation in democracies: What is the role of social capital? Comparative Political Studies, 35, 437-460.

Krishna, A. (2011). Gaining access to public services and the democratic state in India: Institutions in the middle. Studies in Comparative International Development, 46, 98-117.

Lam, W. F. (1997). Institutional design of public agencies and coproduction: A study of irrigation associations in Taiwan. In P. Evans (Ed.), State-society synergy: Government and social capital in development (pp. 11-47). Berkeley, CA: University of California Press.

Ledeneva, A. V. (1998). Russia's economy of favours: Blat, networking and informal exchange. Cambridge: Cambridge University Press.

Li, L. (2004). Political trust in rural China. Modern China, 30, 228-258.

Li, H., Liu, P. W., Zhang, J., and Ma, N. (2007). Economic returns to communist party membership: Evidence from urban Chinese twins. The Economic Journal, 117, 1504-1520.

Li, H., Meng, L., Wang, Q., and Zhou, L. A. (2008). Political connections, financing and firm performance: Evidence from Chinese private firms. Journal of Development Economics, 87, 283-299.

Lieberman, E., Posner, D., and Tsai, L. (2014). Does information lead to more active citizenship? Evidence from an education intervention in rural Kenya. World Development, 60, 69-83. 
Liebman, B. (2011). A populist threat to China's courts? In M.Woo, and M. Gallagher (Eds.), Chinese justice: Civil dispute resolution in contemporary China (pp. 269-313).

Cambridge: Cambridge University Press.

Lorentzen, P. (2014). China's strategic censorship. American Journal of Political Science, 58(2), 402-214.

Lust-Okar, E. (2006). Elections under authoritarianism: Preliminary lessons from Jordan. Democratization, 13, 456-471.

Manor, J. (2000). Small-time political fixers in India's states: "Towel over armpit”. Asian Survey, $40,816-835$.

McGee, R., and Gaventa, J. (2010). Synthesis report: Review of impact and effectiveness of transparency and accountability initiatives. Brighton, UK: Institute of Development Studies.

Michelson, E. (2006). The practice of law as an obstacle to justice: Chinese lawyers at work. Law and Society Review, 40(1), 1-38.

Michelson, E. (2007a). Climbing the dispute pagoda: grievances and appeals to the official justice system in rural China. American Sociological Review, 72(3), 459-485.

Michelson, E. (2007b). Lawyers, political embeddedness, and institutional continuity in China's transition from socialism, American Journal of Sociology, 113(2), 352-414.

Milgram, S. (1967). The small-world problem. Psychology Today, 1, 62-67.

Nathan, A. J. (2003). Authoritarian resilience. Journal of Politics, 14, 6-17.

O'Brien, K., and Li, L. (2004). Suing the local state: Administrative litigation in rural China. The China Journal, 51, 75-96.

Rosenstone, S., and Hansen, J. M. (1993). Mobilization, participation, and democracy in America. New York, NY: Macmillan Publishing Company.

Rozelle, S. (1996). Stagnation without equity: Patterns of growth and inequality in China's rural economy. The China Journal, 35, 63-96.

Ruud, A. E. (2000). Corruption as everyday practice: The public-private divide in local Indian society. Forum for Development Studies, 27(2), 271-294.

Scott, J. (1972). Patron-client politics and political change in Southeast Asia. American Political Science Review, 36, 91-113.

Shi, T. (1997). Political participation in Beijing. Cambridge, MA: Harvard University Press. 
Singerman, D. (1995). Avenues of participation: Family, politics, and networks in urban quarters of Cairo. Princeton, NJ: Princeton University Press.

Tarrow, S. (1998). Power in Movement: Social Movements and Contentious Politics. Cambridge University Press, New York: NY.

Travers, J., and Milgram, S. (1969). An experimental study of the "small-world" problem. Sociometry, 32, 425-443.

Truex, R. (2014). The returns to office in a "rubber stamp" parliament. American Journal of Political Science, 108, 235-251.

Verba, S., Nie, N. H., \& Kim, J. O. (1978). Participation and political equality: A seven-nation comparison. Cambridge: Cambridge University Press.

Verba, S., Schlozman, K., and Brady, H. (1995). Voice and equality: civic voluntarism in American politics. Cambridge, MA: Harvard University Press.

Webb, M. (2012). Activating citizens, remaking brokerage: Transparency activism, ethical scenes, and the urban poor in Delhi. Political and Legal Anthropology Review, 35(2), 206-222.

Wolfinger, R. E., \& Rosenstone, S. J. (1980). Who votes? New Haven: Yale University Press.

\section{Online Appendix for}

Outspoken Insiders: Political Connections and Citizen Participation in Authoritarian China By Lily L. Tsai and Yiqing Xu

\section{Table of Contents}

- Table 1: Descriptive statistics

- Table 2: Robustness check: linear probability models

- Table 3: Robustness check: additional controls - urban residents

- Table 4: Robustness check: additional controls - rural villages

- Table 5: Connections and political knowledge

- Table 6: Connections and access: urban residents 
- Table 7: Connections and access: rural villagers

- Table 8: Mechanisms: Perceptions of government corruption and malfeasance

- Table 9: Definitions of variables: urban survey

- Table 10: Definitions of variables: rural survey 
APPENDIX TABLE 1: DESCRIPTIVE STATISTICS

\begin{tabular}{lccc}
\hline \hline \multicolumn{1}{c}{ Urban } & All & $\begin{array}{c}\text { With } \\
\text { Connections }\end{array}$ & $\begin{array}{c}\text { Without } \\
\text { Connections }\end{array}$ \\
\hline & & & \\
Observations & 6,128 & 745 & 5,383 \\
Observation \% & 100 & 12.0 & 88.0 \\
Overall public service satisfaction rate (1-10) & 7.03 & 7.11 & 7.02 \\
Complaining to the government & 0.15 & 0.25 & 0.14 \\
Age & 0.04 & 0.06 & 0.04 \\
Years of education & 37.3 & 36.1 & 37.5 \\
Communist Party membership & 0.12 & 0.13 & 0.13 \\
High family income & 0.07 & 0.17 & 0.06 \\
Male & 0.38 & 0.54 & 0.35 \\
Urban Hukou & 0.49 & 0.49 & 0.49 \\
Government official & 0.79 & 0.81 & 0.79 \\
White-collar job & 0.39 & 0.53 & 0.37 \\
\hline & & With & Without \\
& All & Connections & Connections \\
\hline & & & \\
Observations & 1,984 & 422 & 1,562 \\
Observation \% & 100 & 21.3 & 78.7 \\
Average public service satisfaction rate & 0.50 & 0.52 & 0.50 \\
Complaining to the village committee & 0.37 & 0.45 & 0.35 \\
Complaining to fellow villagers & 0.48 & 0.54 & 0.49 \\
Age & 50.2 & 50.0 & 50.2 \\
Years of education & 6.59 & 7.01 & 6.47 \\
Communist Party membership & 0.12 & 0.15 & 0.11 \\
High family asset value & 0.49 & 0.57 & 0.47 \\
Male & 0.60 & 0.64 & 0.58 \\
Village cadre & 0.11 & 0.14 & 0.10 \\
Non-agricultural, non-government job & 0.28 & 0.32 & 0.27 \\
\hline Note The & & &
\end{tabular}

Note: The urban data are from CPGS 2013; the rural data are from CRGS 2008. 


\section{APPENDiX TABle 2: CONNECTIONS AND COMPlainT-MAKING:}

LiNEAR PROBABILITY MODELS

\begin{tabular}{|c|c|c|c|c|}
\hline \multirow[t]{2}{*}{ Dependent Variables } & \multicolumn{2}{|c|}{$\begin{array}{l}\text { Urban: Complain to } \\
\text { the Government }\end{array}$} & \multicolumn{2}{|c|}{$\begin{array}{l}\text { Rural: Complain to the } \\
\text { Village Committee }\end{array}$} \\
\hline & $(1)$ & $(2)$ & (3) & $(4)$ \\
\hline Political Connections & $\begin{array}{c}0.085 * * * \\
(0.019)\end{array}$ & $\begin{array}{c}0.085^{* * * *} \\
(0.020)\end{array}$ & $\begin{array}{c}0.106 * * * \\
(0.029)\end{array}$ & $\begin{array}{c}0.082 * * * \\
(0.029)\end{array}$ \\
\hline Years of Education & & $\begin{array}{l}0.005^{* *} \\
(0.002)\end{array}$ & & $\begin{array}{c}0.011^{* * * *} \\
(0.004)\end{array}$ \\
\hline Communist Party Member & & $\begin{array}{c}0.026 \\
(0.023)\end{array}$ & & $\begin{array}{c}0.227 * * * \\
(0.037)\end{array}$ \\
\hline Government Official or Village Cadre & & $\begin{array}{l}-0.043 \\
(0.029)\end{array}$ & & $\begin{array}{c}0.175^{* * * *} \\
(0.038)\end{array}$ \\
\hline Age/10 & & $\begin{array}{c}0.043 \\
(0.029)\end{array}$ & & $\begin{array}{c}0.056 \\
(0.064)\end{array}$ \\
\hline Age-squared/100 & & $\begin{array}{l}-0.004 \\
(0.004)\end{array}$ & & $\begin{array}{l}-0.005 \\
(0.006)\end{array}$ \\
\hline Male & & $\begin{array}{c}0.009 \\
(0.009)\end{array}$ & & $\begin{array}{c}0.067 * * * \\
(0.025)\end{array}$ \\
\hline Urban Hukou & & $\begin{array}{l}-0.012 \\
(0.017)\end{array}$ & & \\
\hline Dependent Variable Mean & 0.153 & 0.151 & 0.373 & 0.373 \\
\hline District/Village Dummies & X & $\mathrm{X}$ & X & X \\
\hline Number of Districts/Villages & 149 & 149 & 101 & 101 \\
\hline Number of Observations & 6,128 & 6,128 & 1,980 & 1,967 \\
\hline Pseudo R-squared & 0.220 & 0.228 & 0.131 & 0.187 \\
\hline
\end{tabular}

Notes: Standard errors clustered by city administrative district (urban) or village (rural) are in the parentheses. Level of statistical significance: $* * * \mathrm{p}<0.01, * * \mathrm{p}<0.05,{ }^{*} \mathrm{p}<0.1$. 


\section{APPENDiX TABle 3: CONNECTIONS ANd COMPLAINT-MAKING OF URBAN RESIDENTS: ADDITIONAL CONTROLS}

\begin{tabular}{|c|c|c|c|c|}
\hline \multirow[t]{2}{*}{ Dependent Variables } & \multicolumn{4}{|c|}{ Complain to the Government } \\
\hline & (1) & $(2)$ & (3) & (4) \\
\hline Political Connections & $\begin{array}{c}0.067 * * * \\
(0.015)\end{array}$ & $\begin{array}{c}0.070^{* * * *} \\
(0.015)\end{array}$ & $\begin{array}{c}0.069 * * * \\
(0.015)\end{array}$ & $\begin{array}{r}0.067 * * * * \\
(0.015)\end{array}$ \\
\hline Trust & $\begin{array}{l}0.030 * \\
(0.018)\end{array}$ & & & $\begin{array}{l}0.029^{*} \\
(0.018)\end{array}$ \\
\hline White-collar Job & & $\begin{array}{l}-0.002 \\
(0.013)\end{array}$ & & $\begin{array}{l}-0.011 \\
(0.014)\end{array}$ \\
\hline High Family Income & & & $\begin{array}{c}0.012 \\
(0.013)\end{array}$ & $\begin{array}{c}0.009 \\
(0.014)\end{array}$ \\
\hline Dependent Variable Mean & 0.175 & 0.173 & 0.173 & 0.175 \\
\hline District Dummies & $\mathrm{X}$ & $\mathrm{X}$ & $\mathrm{X}$ & $\mathrm{X}$ \\
\hline Controls & $\mathrm{X}$ & $\mathrm{X}$ & $\mathrm{X}$ & $\mathrm{X}$ \\
\hline Number of Districts & 124 & 125 & 125 & 124 \\
\hline Number of Observations & 4,874 & 5,182 & 5,182 & 4,874 \\
\hline Pseudo R-squared & 0.195 & 0.196 & 0.197 & 0.195 \\
\hline
\end{tabular}

Notes: This table reports the marginal effects of the independent variables at sample means, estimated by a logistic model. Standard errors clustered by city administrative district are in the parentheses. Age (level and quadratic terms), gender, years of education, Communist Party membership, government official status, urban Hukou status, as well as district fixed effects are controlled for in all the regressions. Level of statistical significance: $* * * \mathrm{p}<0.01, * * \mathrm{p}<0.05, * \mathrm{p}<0.1$. 
ApPendix Table 4: Connections AND Complaint-Making OF RuRAL VillagERS: ADDITIONAL CONTROLS

\begin{tabular}{lcccc}
\hline \hline & \multicolumn{4}{c}{ Complain to Village Cadres } \\
\cline { 2 - 5 } & $(1)$ & $(2)$ & $(3)$ & $(4)$ \\
\hline & $0.080^{* * *}$ & $0.079^{* * *}$ & $0.076^{* *}$ & $0.077^{* *}$ \\
Political Connections & $(0.027)$ & $(0.027)$ & $(0.027)$ & $(0.027)$ \\
& & & & \\
Trust & $0.078^{* *}$ & & & $0.080^{* *}$ \\
& $(0.031)$ & & & $(0.031)$ \\
Non-agricultural, Non-govt. Job & & 0.006 & & 0.007 \\
& & $(0.029)$ & & $(0.030)$ \\
High Family Asset Value & & & $0.036^{*}$ & $0.037^{*}$ \\
& & & $(0.021)$ & $(0.021)$ \\
Dependent Variable Mean & 0.373 & 0.373 & 0.373 & 0.373 \\
Village Dummies & $\mathrm{X}$ & $\mathrm{X}$ & $\mathrm{X}$ & $\mathrm{X}$ \\
Controls & $\mathrm{X}$ & $\mathrm{X}$ & $\mathrm{X}$ & $\mathrm{X}$ \\
Number of Villages & 101 & 101 & 101 & 101 \\
Number of Observations & 1,967 & 1,967 & 1,967 & 1,967 \\
Pseudo R-squared & 0.164 & 0.161 & 0.162 & 0.165 \\
\hline Notes: This tablep
\end{tabular}

Notes: This table reports the marginal effects of the independent variables at sample means, estimated by a logistic model. Standard errors clustered by village are in the parentheses. Age (level and quadratic terms), gender, years of education, village cadre status, as well as village fixed effects are controlled for in all the regressions. Level of statistical significance: $* * * \mathrm{p}<0.01, * * \mathrm{p}<0.05,{ }^{*} \mathrm{p}<0.1$. 
APPENDiX TABle 5: Connections ANd Political KNOWLEdGe

\begin{tabular}{|c|c|c|c|c|c|c|}
\hline \multirow[b]{2}{*}{ Dependent Variables } & \multicolumn{3}{|c|}{ Urban } & \multicolumn{3}{|c|}{ Rural } \\
\hline & $\begin{array}{c}\text { Access } \\
\text { Government } \\
\text { Documents } \\
(1) \\
\end{array}$ & $\begin{array}{c}\text { Know } \\
\text { Mayor's } \\
\text { Name } \\
(2) \\
\end{array}$ & $\begin{array}{l}\text { Use Email } \\
\text { Regularly } \\
\text { (3) }\end{array}$ & $\begin{array}{c}\text { Know } \\
\text { Township } \\
\text { Head's } \\
\text { Name } \\
(4)\end{array}$ & $\begin{array}{l}\text { Know } \\
\text { Governor's } \\
\text { Name } \\
(5) \\
\end{array}$ & $\begin{array}{c}\text { Read } \\
\text { Newspapers } \\
(6) \\
\end{array}$ \\
\hline Political Connections & $\begin{array}{l}0.045^{*} \\
(0.025)\end{array}$ & $\begin{array}{c}0.068 * * * \\
(0.023)\end{array}$ & $\begin{array}{c}0.044 * * \\
(0.024)\end{array}$ & $\begin{array}{c}0.124 * * * \\
(0.023)\end{array}$ & $\begin{array}{c}0.043 * * \\
(0.021)\end{array}$ & $\begin{array}{c}0.046^{* *} \\
(0.021)\end{array}$ \\
\hline Dependent Variable Mean & 0.695 & 0.416 & 0.237 & 0.350 & 0.270 & 0.155 \\
\hline District/Village Dummies & $\mathrm{X}$ & $\mathrm{X}$ & $\mathrm{X}$ & $\mathrm{X}$ & $\mathrm{X}$ & $\mathrm{X}$ \\
\hline Controls & $\mathrm{X}$ & $\mathrm{X}$ & $\mathrm{X}$ & $\mathrm{X}$ & $\mathrm{X}$ & $\mathrm{X}$ \\
\hline Number of Districts/Villages & 137 & 144 & 134 & 98 & 97 & 90 \\
\hline Number of Observations & 4,904 & 5,580 & 4,000 & 1,912 & 1,893 & 1,744 \\
\hline Pseudo R-squared & 0.191 & 0.225 & 0.255 & 0.274 & 0.241 & 0.286 \\
\hline
\end{tabular}




\section{APPENDIX TABLE 6: CONNECTIONS AND ACCESS: URBAN RESIDENTS}

\begin{tabular}{|c|c|c|c|}
\hline Dependent Variables & $\begin{array}{c}\text { Use } \\
\text { Connections to } \\
\text { Secure Better } \\
\text { Public Services } \\
\text { (1) } \\
\end{array}$ & $\begin{array}{l}\text { Deal with the } \\
\text { Government } \\
\text { (2) }\end{array}$ & $\begin{array}{c}\text { "Pull Strings" } \\
\text { (3) }\end{array}$ \\
\hline Political Connections & $\begin{array}{c}0.112 * * * \\
(0.017)\end{array}$ & $\begin{array}{c}0.106 * * * \\
(0.017)\end{array}$ & $\begin{array}{c}0.089 * * * \\
(0.013)\end{array}$ \\
\hline Dependent Variable Mean & 0.229 & 0.149 & 0.089 \\
\hline District Dummies & $\mathrm{X}$ & $\mathrm{X}$ & $\mathrm{X}$ \\
\hline Controls & $\mathrm{X}$ & $\mathrm{X}$ & $X$ \\
\hline Number of Districts & 126 & 129 & 90 \\
\hline Number of Observations & 5,105 & 5,254 & 3,923 \\
\hline Pseudo R-squared & 0.183 & 0.149 & 0.163 \\
\hline \multicolumn{4}{|c|}{$\begin{array}{l}\text { Notes: This table reports the marginal effects of the independent variables at sample means, } \\
\text { estimated by a logistic model. Age (level and quadratic terms), gender, years of education, } \\
\text { Communist Party membership, government official status, urban Hukou status, as well as } \\
\text { district fixed effects are controlled for in all the regressions. Level of statistical significance: } \\
* * * p<0.01, * * p<0.05, * p<0.1 \text {. }\end{array}$} \\
\hline
\end{tabular}

\section{APPENDIX TABle 7: CONNECTIONS AND ACCESS: RuRAL VILLAGERS}

\begin{tabular}{|c|c|c|c|c|c|}
\hline \multirow[b]{2}{*}{ Dependent Variables } & \multirow{2}{*}{$\begin{array}{c}\text { Cadres Allow } \\
\text { Villagers to Express } \\
\text { Views } \\
\text { (1) }\end{array}$} & \multicolumn{4}{|c|}{ The Government Welcomes Complaints } \\
\hline & & $\begin{array}{c}\text { Township } \\
\text { (2) }\end{array}$ & $\begin{array}{c}\text { County } \\
(3)\end{array}$ & $\begin{array}{c}\text { Provincial } \\
(4)\end{array}$ & $\begin{array}{c}\text { Central } \\
\text { Government } \\
(5) \\
\end{array}$ \\
\hline Political Connections & $\begin{array}{c}0.110 * * * \\
(0.025)\end{array}$ & $\begin{array}{c}0.081 * * * \\
(0.025)\end{array}$ & $\begin{array}{c}0.061^{* *} \\
(0.025)\end{array}$ & $\begin{array}{c}0.031 \\
(0.031)\end{array}$ & $\begin{array}{c}0.001 \\
(0.025)\end{array}$ \\
\hline Dependent Variable Mean & 0.651 & 0.410 & 0.474 & 0.580 & 0.760 \\
\hline Village Dummies & X & X & X & X & X \\
\hline Controls & $\mathrm{X}$ & $\mathrm{X}$ & $\mathrm{X}$ & $\mathrm{X}$ & $\mathrm{X}$ \\
\hline Number of Villages & 100 & 101 & 101 & 100 & 101 \\
\hline Number of Observations & 1,939 & 1,962 & 1,959 & 1,932 & 1,957 \\
\hline Pseudo R-squared & 0.137 & 0.105 & 0.086 & 0.065 & 0.079 \\
\hline
\end{tabular}

Notes: This table reports the marginal effects of the independent variables at sample means, estimated by a logistic model. Village fixed effects are controlled for in all the regressions. Age (level and quadratic terms), gender, years of education, Communist Party membership, and village cadre status are controlled for as well. Level of statistical significance: *** $\mathrm{p}<0.01, * * \mathrm{p}<0.05, * \mathrm{p}<0.1$. 


\section{ApPendix Table 8: Perceptions of Government CoRruption AND MALFEASANCE}

\begin{tabular}{|c|c|c|c|c|}
\hline \multirow[b]{2}{*}{ Dependent Variables } & \multicolumn{4}{|c|}{ Urban } \\
\hline & $\begin{array}{c}\text { Unfair } \\
\text { Privilege of } \\
\text { Officials } \\
\text { (1) }\end{array}$ & $\begin{array}{c}\text { Improper Fees } \\
\text { (2) }\end{array}$ & $\begin{array}{l}\text { Improper } \\
\text { Fines } \\
(3)\end{array}$ & $\begin{array}{c}\text { Corruption } \\
\text { (4) }\end{array}$ \\
\hline Political Connections & $\begin{array}{c}0.079 * * * \\
(0.022)\end{array}$ & $\begin{array}{l}0.039^{*} \\
(0.021)\end{array}$ & $\begin{array}{c}0.055^{* *} \\
(0.020)\end{array}$ & $\begin{array}{l}-0.011 \\
(0.030)\end{array}$ \\
\hline Dependent Variable Mean & 0.591 & 0.150 & 0.135 & 0.309 \\
\hline District Dummies & $\mathrm{X}$ & $\mathrm{X}$ & $\mathrm{X}$ & X \\
\hline Controls & $\mathrm{X}$ & $X$ & $\mathrm{X}$ & $\mathrm{X}$ \\
\hline Number of Districts & 139 & 89 & 80 & 124 \\
\hline Number of Observations & 5.469 & 3.426 & 3,095 & 4,672 \\
\hline \multirow[t]{3}{*}{ Pseudo R-squared } & 0.219 & 0.194 & 0.222 & 0.170 \\
\hline & \multicolumn{4}{|c|}{ Rural } \\
\hline & $\begin{array}{c}\text { Not All } \\
\text { Villagers } \\
\text { Benefit from } \\
\text { Public } \\
\text { Investment } \\
(1) \\
\end{array}$ & $\begin{array}{c}\text { Villagers } \\
\text { Treated } \\
\text { Unequally } \\
(2)\end{array}$ & $\begin{array}{l}\text { Cadres } \\
\text { Benefit the } \\
\text { Most from } \\
\text { Reform } \\
\text { (3) }\end{array}$ & $\begin{array}{c}\text { Corruption } \\
\text { (4) }\end{array}$ \\
\hline Political Connections & $\begin{array}{l}-0.026 \\
(0.020)\end{array}$ & $\begin{array}{c}-0.103^{* * *} * \\
(0.029)\end{array}$ & $\begin{array}{l}-0.005 \\
(0.027)\end{array}$ & $\begin{array}{l}-0.048 \\
(0.031)\end{array}$ \\
\hline Dependent Variable Mean & 0.175 & 0.290 & 0.710 & 0.432 \\
\hline Village Dummies & $\mathrm{X}$ & $\mathrm{X}$ & $\mathrm{X}$ & $\mathrm{X}$ \\
\hline Controls & $\mathrm{X}$ & $\mathrm{X}$ & $\mathrm{X}$ & $\mathrm{X}$ \\
\hline Number of Villages & 94 & 101 & 101 & 101 \\
\hline Number of Observations & 1,831 & 1,964 & 1,971 & 1,885 \\
\hline Pseudo R-squared & 0.090 & 0.102 & 0.081 & 0.080 \\
\hline
\end{tabular}

Notes: This table reports the marginal effects of the independent variables at sample means, estimated by a logistic model. In the upper panel, age (level and quadratic terms), gender, years of education, Communist Party membership, government official status, urban Hukou status, as well as district fixed effects are controlled for in all four regressions. In the lower panel, age (level and quadratic terms), gender, years of education, Communist Party membership, village cadre status, as well as village fixed effects are controlled for in all four regressions. Level of statistical significance: $* * * p<0.01, * * \mathrm{p}<0.05, * \mathrm{p}<0.1$. 
APPENDIX TABLE 9: DEFINITIONS OF VARIABLES: URBAN

\begin{tabular}{ccc}
\hline \hline Variable Name & Related Survey Question & Coding \\
\hline
\end{tabular}

\section{Political}

Connections

Political connections

Do you have relatives working in the government?

您家是否有亲戚家人在政府部门工作？

\section{Complaint-making}

Complain to the local government

\section{Satisfaction \\ Happiness}

Satisfaction with standard of living

Satisfaction towards local public services
During the past year, have you ever raised suggestions, complaints and dissatisfaction against the local government or government officials in the following ways? Options: (1) complain through government hotline; (2) complain to government offices; (3) complain to higher-level government (including petitions); (4) contact higher level officials in private; (5) complain to local PC/CPPCC; (6) complain to party disciplinary bodies; (7) complain to local party committees/branches; (8) contact local officials in private; (9) complain to government officials directly; (12) small-scale protest; (13) contact media; (10) complain online (e.g. through gov. websites); (14) complain through other measures. 在过去一年中, 您是否曾以下列方式表达对本地政府或政府 官员的意见、抱怨或不满（逐条回答）？选项：（1）政府公 开的监督电话/一把手热线、（2）向本地政府部门反映、

（3）向上级政府部门反映（包括上访）、（4）给领导、政 府官员写信或直接反映情况、（5）通过本地人大、政协来反 映、（6）通过纪检部门报告、（7）通过所属党委、党支部 提出、（8）私下联系认识的本地政府官员、（9）私下联系 认识的上级政府官员、(10) 网络途径 (例如在政府网站留 言）、（11）搜集签名向有关部门递交要求、（12）集体行 动 (访问员口头表述: 小规模抗议) 、（13）联系媒体 (报 社或电视台记者、编辑）、（14）以其他方式表达。

In general, do you feel happy about your life? 总体上, 您自己对现在的生活感到幸福吗? 请用 $1 \sim 10$ 分进 行打分, 分数越高表示越幸福, 其中 10 分代表非常幸福。

Are you satisfied with the living conditions of your family? 您对家里现在的生活条件感到满意吗？请用 $1 \sim 10$ 分进行打 分, 分数越高表示越满意, 其中 10 分代表非常满意。

Please score the following public services provided by the municipal government using a 1-10 scale. 10 means very satisfactory; 1 means very unsatisfactory. (1) health care; (2) pension and social security; (3) public transportation; (4) city environment; (5) city infrastructure; (6) public security; (7) public health; (8) water; (9) electricity; (10) sewage; (11) public education. 请您给本市政府提供的各项公共服务打分，用 $1 \sim 10$ 分表 示, 分数越高表示越满意, 其中 10 分代表非常满意, 1 分代
$1=$ yes, as ordinary public servants/clerks; yes, as high rank officials; $0=$ no; refuse to answer; unable to answer. 1 = 有, 做普通公务员/普通职员; 有, 担任一定领导职务; $0=$ 没 有。

$1=$ yes; $0=$ no.

Scale: $1-10$

Scale: $1-10$

The average of 11 scores. 
Information Skills

Access public documents
表非常不满意。（1）医疗、（2）养老保障、（3）公共交 通、（4）环境绿化、（5）城市基础设施建设、（6）社会治

安、（7）公共卫生、（8）供水、（9）供电、（10）下水

道、垃圾处理、（11）教育。

When you need to know about a piece of local government statute, can you find a copy of the statute quite easily?

如果您需要了解当地政府某项制度规定, 是否能很容易找到 需要的文件?

Know the mayor's name

Use email regularly

\section{Access to the}

Government

Use connections to secure better public services

Deal with the government

"Pull strings"

\section{Perception of the government}

Unfair privilege

Improper fees

Improper fees

Government officials corrupt
Do you know who the Party Secretary of this city is and who is the mayor?

请问您是否知道本市的市委书记是谁？市长是谁？

Do you use emails regularly?

您经常发送电子邮件吗?

Have you or your family members ever tried to use connections to obtain better public services, such as education and health care?

为了升学、看病或为了获得其他公共服务, 您或您的家人是 否曾托过关系、走过后门?

During the past year, have you ever dealt with government agencies?

在过去一年中，您是否到政府机构办过事？

Have you ever attempted to "pull strings" when you dealt with government agencies?

您到政府办事时, 是否曾经找人走过关系?

During the past year, have you ever heard about that government officials and their relatives enjoy unfair privileges?

最近一年里, 您有没有听说过政府部门有关人员及其家属使 用特权的情况?

As far as you know, do you think doing petty trade will encounter improper fees in this city? 据您所知，在本市做小生意是否会碰到乱收费的情况？

As far as you know, do you think doing petty trade will encounter improper fines in this city? 据您所知, 在本市做小生意是否会碰到无故罚款的情况?

Do you think that local government officials are corrupt?
$1=\mathrm{I}$ can easily find whatever I want from publicly available sources; I can, as long as the information is publicly available. $0=$ most information is publicly available, but it is not easy to find what I want; it hard to get the information.

$1=$ 只要是我想找的, 都可以方便 地通过公开途径获得、信息大部分 是公开的, 并且能比较容易地找 到、信息大部分是公开的, 但是 不容易找到; $0=$ 信息很难了解, 几乎找不到。

$1=$ know at least one of them; $0=$ otherwise.

$1=$ 至少知道其中一位; $0=$ 其

他。

$1=$ very often; $0=$ occasionally, never. $1=$ 经常用; $0=$ 偶尔用、从来不 用。

$1=$ yes; $0=$ no.

$1=$ 是; $0=$ 否。

$1=$ yes; $0=$ no.

$1=$ 是; $0=$ 否。

$1=$ yes; $0=$ no.

$1=$ 有; $0=$ 没有。

$1=$ often heard, heard once or twice; $0=$ never.

$1=$ 经常听说、听说过一两次; $0=$ 没有听说过。

1 = often, occasionally; $0=$ never.

$1=$ 经常发生、偶尔发生; $0=$ 从 来没发生过。

1 = often, occasionally; $0=$ never.

$1=$ 经常发生、偶尔发生; $0=$ 从 来没发生过。

$1=$ all of them are corrupt, most of them are corrupt; $0=$ 
您认为当地政府官员有没有腐败的情况?

\section{Individual}

\section{characteristics}

Years of education

Communist Party

member

Government official status

White-collar

Urban Hukou status

Trust

High family income
What is your highest degree attained?

您的最高学历是?

What is your political identity?

您的政治面貌是?

What is your occupation?

请问您的职业是？

What is your occupation?

请问您的职业是?

What is your current Hukou (household registration) status?

\section{请问您目前的户口情况？}

Assume that you are going to be out of town for a while, if it is necessary, will you consider leaving the keys to your house to your neighbors in case there is an emergency?

假设您要出远门一段时间, 如果有必要, 您会不会考虑把家 里的钥匙交给邻居以便应付一些紧急情况?

Which interval does your monthly family income belong to? none of them are corrupt, a few of them are corrupt, half of them are corrupt.

$1=$ 全都腐败、大多数官员是腐败

的; $0=$ 没有腐败、少数官员腐

败、估计一半官员是腐败的。

$5=$ primary school or below; $9=$ junior high school; $12=$ middle school; $15=$ junior college; $16=$ college; $19=$ master degree; 21 = doctoral degree.

$5=$ 小学及以下; $9=$ 初中; $12=$ 高中/中专/技校; $15=$ 大专; $16=$ 大学本科; $19=$ 硕士研究生; 21

$=$ 博士研究生

$1=$ Communist Party member; $0=$ Others

$1=$ 中共党员; $0=$ 其他。

1 = high-level cadre, mid-

level cadre, or staff in government apparatus etc.; 0 $=$ otherwise.

$1=$ 党政机关/社会团体/事业单位

的高层干部、中层干部、普通办

公室职员； $0=$ 其他。

$1=$ entrepreneur, top

management, middle

management, clerk,

technician, researcher; $0=$ otherwise.

$1=$ 企业高层管理人员、中层管理 人员、普通办公室职员/业务员/办 事人员、高级专业技术人员（如律 师、教师、会计、医生、记者、IT 工程师等）； $0=$ 其他。

1 = local, urban; 0 = local, rural; nonlocal, urban; nonlocal, rural.

$1=$ 本地城镇; $0=$ 本地农村、外 地城镇、外地农村。

1 = yes; $0=$ no.

$1=$ 会; $0=$ 不会。

$1=$ above city median family income interval; $0=$ otherwise

TABLE A10. DEFINITIONS OF VARIABLES (CONTINUED): RURAL

\begin{tabular}{ccc}
\hline \hline Variable Name & Related Survey Question & Coding \\
\hline
\end{tabular}

\section{Political connections}


Political connections

\section{Complaint-making}

Complain to village cadres

Complain to fellow villagers

\section{Satisfaction}

Satisfaction towards the village committee

Satisfaction towards the township government

Satisfaction towards public services

\section{Information Skills}

Know the township head's name

Know the governor's name

Read newspapers

\section{Access to the Government}

Agree that cadres allow villages to express views

Agree that the township government welcomes
Do you have any relatives who are village cadres or have worked in higher levels of government such as the township, county or provincial government?

你们家有亲戚是村干部或在上级政府工作吗，如乡镇政 $1=$ 是; $0=$ 不是。 府、县政府或者省政府?

Have you raised problems of public projects with village cadres? 关于公共项目质量的问题，你跟村干部提过 $1=$ 是; $0=$ 不是。 吗?

Have you raised problems of public projects with other villagers?

关于公共项目质量的问题，你跟其他村民提过吗?

How much time and energy do you think village cadres actually spend on public projects?

你觉得村干部在公共投资项目上实际投入了多少时间和 精力?

How much time and energy do you think township cadres actually spend on public projects?

你觉得乡镇干部在公共投资项目上实际投入了多少时间 和精力?

Are you satisfied with public services provided by the village committee: (1) roads; (2) schooling; (3) clinics; (4) clean water; (5) irrigation; (6) sewage; (7) social organizations, such as agricultural technology associations; (8) the elderly's society.

您对村里提供的公共服务是否满意?（1）道路、（2） 学校、（3）卫生室、（4）生活用水、（5）灌溉设 施、（6）排水设施、（7）社区组织, 如农民专业技术 协会等、（8）老年协会。

Do you know whom the current township head or Party secretary is?

\section{你知道现在的乡长或乡镇党委书记是谁吗?}

Do you know whom the current provincial head or secretary is?

\section{你知道现在的省长或省委书记是谁吗?}

Do you usually read newspapers? 你平常看报纸吗?

Do you think village cadres give villagers opportunities to express their views 村干部做决定时是否给村民们表达看法的机会? Do you think the township government welcomes villagers to complain about 项取均值。

$$
1=\text { yes; } 0=\text { no. }
$$

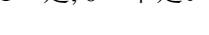$$
1=\text { 是; } 0=\text { 不是。 }
$$

$$
\begin{aligned}
& 1=\text { yes } ; 0=\text { no. } \\
& 1=\text { 是; } 0=\text { 不是。 } \\
& 1=\text { yes } ; 0=\text { no. } \\
& 1=\text { 是; } 0=\text { 不是。 }
\end{aligned}
$$

$1=$ a lot; much; $0=$ relatively little; very little.

$1=$ 很多、比较多; $0=$ 比较少、很 少。

$1=$ a lot; much; 0 = relatively little; very little.

$1=$ 很多、比较多; $0=$ 比较少、很 少。

1 = Very satisfied; satisfied; 0 $=$ Not satisfied. Then we take an average of the 8 items.

$1=$ 非常满意、满意; $0=$ 不满意。 8

$1=$ yes if they can say the person's surname; no $=$ otherwise. $1=$ 知道（只说对姓氏也算）, $2=$ 不 知道

$1=$ yes if they can say the person's surname; no = otherwise. $1=$ 知道（只说对姓氏也算）, $2=$ 不 知道

$1=$ yes; $0=$ no.

$1=$ 看 $; 0=$ 不看。

$$
\begin{aligned}
& 1=\text { yes } ; 0=\text { no. } \\
& 1=\text { 是; } 0=\text { 否。 } \\
& 1=\text { yes; } 0=\text { no. }
\end{aligned}
$$


complaints

Agree that the county government welcomes complaints

Agree that the provincial government welcomes complaints

Agree that the central government welcomes complaints

\section{Perception of the government}

Not all villagers get benefits

Villagers treated unequally

Cadre benefit the most from reform

Corruption

\section{Individual characteristics}

Years of education

Village cadre

Non-agricultural, nongovernment job

Trust

High family asset value problems?

在你看来, 乡镇政府是不是欢迎农民去反映问题?

$1=$ 是; $0=$ 否。

Do you think the county government welcomes $1=$ yes; $0=$ no.

villagers to complain about problems?

在你看来，县政府是不是欢迎农民去反映问题? $\quad 1=$ 是; $0=$ 否。

Do you think the provincial government $\quad 1=$ yes; $0=$ no.

welcomes villagers to

complain about problems?

在你看来，省委省政府是不是欢迎农民去反映问题? $\quad 1=$ 是; $0=$ 否。

Do you think the central government welcomes $1=$ yes; $0=$ no.

villagers

to complain about problems?

在你看来，中央政府是不是欢迎农民去反映问题? $\quad 1=$ 是; $0=$ 否。

Do all villagers benefit from the village's public investment projects?

是否全体村民都从村里的公共投资项目中受益?

Do village cadres treat all villagers equally?

村干部是否对所有村民一视同仁?

Who benefits most in the reform process?

在改革过程中, 谁得到的好处最多?

Compared with a decade ago, do you think the government is cleaner?

和十年前的政府相比，你觉得现在政府的廉洁情况怎么 样?

$1=$ No; $0=$ Yes (note that we flip the answer).

$1=\mathrm{No} ; 0=$ Yes (note that we flip the answer).

$1=$ 否; $0=$ 是。

1 = village cadres; higher level cadres; $0=$ ordinary villagers $1=$ 村干部、国家干部; $0=$ 普通村

民

1 = much less clean, less clean; the same; $0=$ much cleaner, cleaner.

$1=$ 减少了很多、减少了一点、保持 原样; $0=$ 廉洁了很多、廉洁了一点

What is your level of education?

5 = primary school or below; 9 $=$ junior high school; $12=$ high school; $15=$ junior college; 16 $=$ college or above

\section{你的教育程度是?}

Are you a Communist Party member?

你是不是党员?

What is major non-agricultural job last year?

去年最主要的非种养工作是?

$5=$ 小学及以下; $9=$ 初中 $; 12=$ 高

中/中专/技校; $15=$ 大专; $16=$ 大

学以上

1 = yes; $0=$ no.

$1=$ 是; $0=$ 不是。

$1=$ village cadre; $0=$

otherwise.

$1=$ 村、组干部; $0=$ 其他。

Do you have non-agricultural income last year?

去年你是否有非种养业收入?

Say you had to leave the house to do something and you had a three or four year old child who needed someone to look after them, would you leave the child with another villager to look after?

假设你临时要出门办事, 家里有一个三岁左右的小孩需 要照看，你会不会把这个小孩交给别的村民照看?

Total family asset at the end of last year (farm tools, draught animals, and furniture). 去年年底家庭资产总额（农具、役畜和家具）。
$1=$ Yes (and the respondent is not a village cadre); $0=$ No. $1=$ 是（但非村、组干部）; $0=$ 否。 $1=$ yes, but only with a relative, friend, or neighbor; yes, any villager who gets along with me; $0=$ no, I would take them with me; other.

$1=$ 会, 但必须是亲戚朋友或邻居; 会, 只要不是冤家; $0=$ 不会, 肯定 自己带着; 其它。

$1=$ above city median family income interval; $0=$ otherwise 
